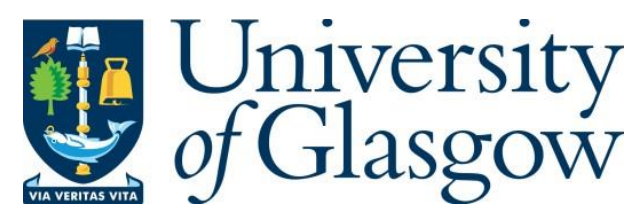

Matthews, R. S., Chalmers, D. M. and Fraser, S. S. (2018) The intersection of entrepreneurship and selling: an interdisciplinary review, framework, and future research agenda. Journal of Business Venturing, 33(6), pp. 691-719.

There may be differences between this version and the published version. You are advised to consult the publisher's version if you wish to cite from it.

http://eprints.gla.ac.uk/180345/

Deposited on: 11 March 2019

Enlighten - Research publications by members of the University of Glasgow http://eprints.gla.ac.uk 


\title{
The Intersection of Entrepreneurship and Selling: An Interdisciplinary Review, Framework, and Future Research Agenda
}

\section{Published in Journal of Business Venturing (in press)}

\author{
Russell Matthews*, Dominic Chalmers*, Simon Fraser ${ }^{+}$ \\ * Hunter Centre for Entrepreneurship, University of Strathclyde, Glasgow G1 1XQ, Scotland, UK \\ +Centre for Entrepreneurship, Robert Gordon University, Aberdeen AB10 7QE, Scotland, UK
}

\begin{abstract}
A B S T R A C T
Selling is integral to entrepreneurship, yet it has rarely been a focal topic of analysis for entrepreneurship scholars. To address this, we undertake a broad-ranging systematic literature review of research that in some way explores selling within entrepreneurial contexts. We inductively develop a framework that orders extant research into selling antecedents, activities, contexts, and outcomes. Then, drawing on these entrepreneurship-selling intersections, we suggest opportunity theory can be extended by integrating critical insights from selling literatures. In particular, we address ego-centric views of entrepreneurship which prioritize entrepreneurial agency, and advocate for the incorporation of customer agency into synchronized processes of opportunity identification, refinement, and exploitation. The article concludes that a promising avenue for future theory development resides in the study of situated sales interactions, which can serve as an empirical vista to the underexplored entrepreneur-customer nexus.
\end{abstract}

\section{Executive Summary}

The aim of this article is to provide a foundational understanding of the theoretical intersections that exist between entrepreneurship and selling. We contend that selling is a fundamental entrepreneurial activity, but that it is rarely an area of focus within core entrepreneurship theories. We find that there are few empirical or conceptual accounts of selling in entrepreneurship studies, and where selling is addressed, we find that it is commonly in the form of a background description or an implied activity. Understanding of the relationship between selling and entrepreneurship is therefore fragmented and, consequently, 
there is limited integration of selling activities into higher-level theorizing, notably with respect to key entrepreneurship constructs such as 'opportunity'.

To develop a holistic, interdisciplinary understanding of selling in new venture settings, we conduct a systematic literature review that elicits key entrepreneurship-selling intersections. We identify 109 studies drawn from entrepreneurship, sales, marketing, management, strategy, international business, and organisation studies literatures that in some way address selling in an entrepreneurial context. Drawing on our analysis, we advance a multidimensional framework that brings order to extant research and suggests pathways for future streams of entrepreneurship and sales scholarship.

Our framework, which categorizes research evidence into the antecedents, activities, outcomes, and contexts of selling, finds that the literature primarily positions entrepreneur (or firm) capabilities and associated strategic decisions as the key determinants of selling behaviors. There is, however, limited focus on the activities associated with the actual doing of selling, particularly with respect to how entrepreneurs sell in situated social exchanges or how new venture selling capabilities function in a dynamic fashion.

Upon synthesizing the findings of our review with entrepreneurship literature, we critique the tendency of entrepreneurship scholarship to view 'selling' as a somewhat mechanistic activity rather than an embedded and contingent socially orientated process. Such an approach, it is argued, precludes incorporation of the socio-interactional, relational, and material dynamics of sales work - factors that we suggest critically impact the development and exploitation of opportunities. We conclude therefore, that a focus on the entrepreneurshipselling nexus can provide valuable insights into how opportunities are shaped, enacted, and exploited in conjunction with market actors.

Finally, we propose that analysis of selling encounters can empirically anchor future studies that explore the agency of customers in entrepreneurial market exchanges. We suggest 
that through exploiting complementarities with both the marketing and selling literatures' focus on customers, and organization studies' conception of market performativity, the potential to incorporate customer agency into opportunity theory can be more fully realized. Pursuing such an agenda offers the potential to extend existing opportunity theories that largely examine entrepreneurial activity from the narrow epistemological vantage-point of the entrepreneur.

\section{Introduction}

Selling is fundamental to entrepreneurship, yet it has rarely been a focus of entrepreneurship theories. To date, integration between both concepts has been limited, despite early entrepreneurship scholarship explicitly identifying selling as a core activity (Block and MacMillan, 1985). This is evidenced by Moroz and Hindle's (2011) analysis of 32 process models of entrepreneurship, none of which directly conceptualize selling or sales work. Thus, while selling is ever present within studies of entrepreneurial behavior, either as a background description or as an implied activity, understanding of the concept is fragmented and is yet to be fully integrated into higher-level theorizing around opportunities and other entrepreneurship constructs. Such a significant dislocation between theory and practice, we contend, serves as a trigger (Shepherd and Suddaby, 2017) for reconsidering the important role of selling in entrepreneurship research.

Intersections between theoretical concepts and scholarly communities can be a fount of new insight (Lowell et al., 2003; Ireland and Webb, 2007; Webb et al., 2011). The entrepreneurship research field is itself a "multidisciplinary jigsaw" (Harrison and Leitch, 1996: 69) that has its genesis in economics, strategy, and organizational behavior. Significant progress has been made over the previous two decades as scholars have probed the interface between entrepreneurship and related domains of leadership (Cogliser and Brigham, 2004; Reid et al., 2017), international business (McDougall and Oviatt, 2000), strategy (Hitt et al., 
2001), marketing (Morris et al., 2002), and institutional theory (Tolbert et al., 2011). In each case, the nexus between fields has offered a new vantage point from where existing domain knowledge has been reframed, rejected, affirmed, and enhanced.

Extending upon such studies, we use the present article to explore how a stronger conceptualization of the intersections between entrepreneurship and selling may contribute to ongoing debates relating to key market-based constructs such as opportunities (Dimov, 2011; Davidsson, 2015; Shepherd, 2015). We do so by systematically reviewing literature that has examined selling in entrepreneurial contexts, with a view to developing a foundational understanding of the research landscape. This necessarily entails us casting a wide net, not only across entrepreneurship, sales and marketing literatures, but also, in acknowledgement of the pervasive interest in how entrepreneurs sell (Pinch and Clark, 1986), across the wider social sciences Drawing on our analysis of these materials, we integrate our findings with core entrepreneurship theory and offer three primary contributions.

Firstly, we present an inductively developed multidimensional framework that brings order to extant research and suggests pathways for future streams of entrepreneurship and sales scholarship. Our framework, which categorizes research evidence into the antecedents, activities, outcomes, and contexts of selling, finds that the literature positions entrepreneur (or firm) capabilities, and associated strategic decisions, as the primary moderators of sales outcomes. There is, consequently, limited theorization of the actions associated with selling, particularly with respect to dynamic, contextualized, interactive, and multi-agency perspectives. Our analysis allows us to then identify a range of specific research objectives that we believe can further integrate and advance scholarship.

Second, upon synthesizing the findings of our systematic literature review (SLR) with entrepreneurship literature, we contend that selling is frequently taken for granted or omitted from theories of entrepreneurship and propose this has resulted in an incomplete and potentially 
flawed understanding of key market-oriented concepts such as opportunity. We base this critique on the trend within entrepreneurship scholarship to view 'selling' through the mechanistic, neo-classical lens of economic exchange (Alvarez et al., 2013; Swedberg, 2000) and not as an embedded and contingent socially oriented process (Darr and Pinch, 2013). Such an approach, it is argued, precludes incorporation of the socio-interactional, relational and material dynamics of sales work - factors that we suggest critically impact the development and exploitation of opportunities. We conclude therefore, that a focus on the entrepreneurshipselling nexus can provide valuable insights into "the embodiment of knowledge between an entrepreneur and a community" (Shepherd, 2015: 491) as they pursue and shape entrepreneurial opportunities together.

Finally, we propose that analysis of selling encounters can empirically anchor future studies that explore the agency of customers in entrepreneurial market exchanges. We suggest that through exploiting complementarities with both the marketing and selling literatures' focus on customers (Webb et al., 2011; Evans et al., 2012), and organization studies' conception of market performativity (Ahrne et al., 2015), the potential to incorporate customer agency into opportunity theory can be more fully realized. Understanding this agency will, however, require a deeper analysis of the social structural positioning of entrepreneurs and their customers, as well as a greater understanding of the social organization of their locally situated (Darr and Pinch, 2013) and online (Dellarocas, 2003) selling encounters. Pursuing such an agenda offers the potential to extend existing opportunity theories that largely examine entrepreneurial activity from the narrow epistemological vantage-point of the entrepreneur.

We commence our analysis by providing a summarizing overview of the selling and entrepreneurship research domains.

\section{Selling and entrepreneurship in synopsis}




\subsection{Selling}

At its most elemental, 'selling' can be defined as "the act of offering goods and/or services to others in return for receiving money" and 'buying' as "the act of offering money in return for gaining possession of those goods and/or services" (Darr and Pinch, 2013: 1604). It is a socio-interactional practice in which outcomes, according to early research, can be determined by "the social, physical, and personality characteristics" of participants (Evans, 1963: 76). Given that selling has underpinned exchange relationships since early civilization (Butler, 1917; Powers et al., 1987), considerable sociological and anthropological insight into this fundamental human activity has accumulated (e.g. Sahlins, 1965; Plattner, 1989).

The most developed strand of sales research has focused on selling within a marketing context (e.g. Spiro et al., 1976; Dubinsky, 1981; Weitz and Bradford, 1999). Here, selling is considered by some to be an activity-based or tactical foil to the more 'strategic' marketing function (Homburg and Jensen, 2007). In a critical review of sales literature, Plouffe et al (2008) find that sales research has often been atheoretical, typically directing attention towards managerialist aspects of the sales process (Korczynski, 2005) such as salesperson compensation (remuneration), selling techniques, and salesforce motivation (Geiger and Guenzi, 2009).

Over recent years, there has been a marked decline in the number of sales articles published in top marketing journals (Avlonitis and Panagopoulos, 2010). There is perceived to be a relevance gap in which scholars are failing to examine phenomena considered important by industry and other relevant actors; something that has, in turn, been compounded by underdeveloped theorization (Plouffe et al., 2008; Avlonitis and Panagopoulos, 2010). Recently, scholars have attempted to address these criticisms by widening topics of enquiry to include sales ethics, buyer-seller interactions, and seller creativity (Evans et al., 2012). Additionally, there have been methodological advances integrating novel practice-based 
perspectives that connect the performative nature of 'sales work' to developments in organization studies and economic sociology (e.g. Darr, 2011; Darr and Pinch, 2013; Geiger and Kelly, 2014). Despite these important efforts to broaden the theoretical scope of sales research, there remain notable opportunities to rejuvenate theory further still; specifically, we contend, through integration with market-oriented phenomena such as entrepreneurship.

\subsection{Entrepreneurship}

In contrast to selling research, entrepreneurship scholarship remains in the ascent (Carlsson et al., 2013), with a significant volume of studies continuing to penetrate the leading management journals (Busenitz et al., 2014). While entrepreneurship theory has foundations in the works of Smith (1778) and Schumpeter (1934) amongst others, it has only been since the mid 1980s that a discernible research community has coalesced (Carlsson et al., 2013). Despite this comparative adolescence, entrepreneurship has been cited as one of the more dynamic fields of economic and management research (Wiklund et al., 2011).

One of the key theoretical lynchpins of entrepreneurship scholarship is opportunity. Opportunity research is concerned with "how, by whom, and with what effects opportunities to create future goods and services are discovered, evaluated, and exploited" (Shane and Venkataraman, 2000: 218). Paradigmatic debates have addressed competing conceptualizations of opportunities, notably whether they are discovered as objective entities (Shane, 2012) or created through combined human imagination and social interaction (Alvarez and Barney, 2007). Many scholars have also drawn conceptual distinctions between the internal cognitive processes associated with discovery/creation, 'recognition' (Baron and Ensley, 2006), or 'identification' (Shepherd and DeTienne, 2005), and the action-oriented 'exploitation' (de Jong, 2013). The exploitation construct has, in turn, been associated with a broad base of activities, notably resource mobilization and capability building (Sarason et al., 
2006; Choi et al., 2008; Ketchen Jr et al., 2011), but rarely with granular market interactions (Godley, 2013). If, as leading scholars contend, “opportunities are inherently market oriented" (Dimov, 2011: 68), we posit that selling must play an integral role in the enactment of opportunities, particularly with respect to processes of opportunity co-creation undertaken in conjunction with external actors (Sarasvathy, 2001).

The study of market engagement in entrepreneurial contexts has also received considerable attention from marketing scholars. Specifically, the field of entrepreneurial marketing has served as a bridge between the two domains (Jones and Rowley, 2011a). Entrepreneurial marketing diverged from the parent marketing discipline as scholars raised questions concerning the applicability of theory derived from and developed for traditional corporate organizations (Hills et al., 2008). Early empirical findings have confirmed for example, that the age and size of a venture impacts upon marketing activities (Coviello et al., 2000), and hence other core assumptions surrounding the nature of marketing practices in entrepreneurial ventures have since been re-evaluated (Wallnöfer and Hacklin, 2013).

While studies at the intersection of entrepreneurship and marketing have offered many valuable insights, they have not adequately conceptualized how entrepreneurs and entrepreneurial firms sell their new ideas, products and services by engaging and exchanging with potential customers. Given that securing early, or first, sales represents a critical obstacle for new firms (Gatewood et al., 1995; Rehme and Svensson, 2011), and that selling encounters can be a locus of opportunity creation and exploitation, the topic evidently possesses relevance for entrepreneurship and selling scholars. Thus, we seek to answer the following questions in our review and integration: (1) What are the intersections between entrepreneurship and selling in extant research, and, (2) How can a focus on selling enhance our understanding of core entrepreneurship constructs, processes, and practices?

\section{Methodology}


To achieve our objectives, we undertook a systematic literature review which mapped research at the intersection of entrepreneurship and selling. To enhance the validity and rigor of the review, we adhered to established protocols concerning the transparent and replicable analysis of literature sources (e.g. Tranfield et al., 2003; Denyer and Tranfield, 2008). Given that there is no established research field at the intersection of entrepreneurship and selling, we avoided the application of pre-determined analytical categories and instead employed an interpretative and inductive thematic analysis aimed at bringing structure to a diverse collection of research findings (see Macpherson and Holt, 2007; Jones et al., 2011). Our thematic classifications allowed us to develop a broad ranging account of current knowledge, which acted as a basis to forward a well-founded research agenda.

\subsection{Data collection}

We restricted the review to articles published in peer-reviewed journals and designed our collection strategy purposively to cast a wide net over all potentially relevant research. This involved an initial search phase, which provided us with an early sample and a basis upon which to develop further relevant search terms. In phase one, we searched the terms 'sale*' and 'sell*' within the abstract, title, keywords of all entrepreneurship publications listed in the Association of Business Schools Academic Journal Quality Guide, Version.5. We also applied these search terms to a wide range of marketing, strategy, organization studies, and management journals (see Table.1). In order to encourage relevant search returns from nonentrepreneurship journals, we applied an additional set of search filters, designed to extract those discussions of selling that were rooted in entrepreneurial contexts and concepts. Performing an initial analytical sweep of the sample, we then conducted a second collection 
phase using an additional set of relevant terms derived from our examination of the literature. These terms captured broader selling concepts; for example, 'customer participation', 'customer retention', and 'e-commerce' (see Appendix A for a detailed overview of all search terms applied).

As a consequence of our broad collection approach, a large volume of articles were returned (in excess of 2,500), many of which did not fit with the conceptual boundaries of our study. Consequently, we applied a number of exclusion categories (See Appendix B). Following exclusion of non-peer-reviewed articles and those that contained no theorization (e.g. teaching case studies), we also removed articles where sales were discussed solely as a measure of firm performance. We then removed articles that did not examine the sale (or attempted sale) of an offering (product or service) to some form of market actor (i.e. a customer or prospective customer); for example, the 'trade sale' of a firm. Finally, we excluded those articles that discussed selling activities, but gave no reference to entrepreneurship concepts and 
Table 1 Journals searched

\begin{tabular}{ll}
\hline Academic Field & Journal (no. of accepted articles) \\
\hline \multirow{2}{*}{ Entrepreneurship and } & Entrepreneurship Theory and Practice ${ }^{1}$ (6); Journal of Business Venturing (14); \\
& Strategic Entrepreneurship Journal (1); Entrepreneurship and Regional Development \\
& (2); Family Business Review (1); International Small Business Journal (4); Journal of \\
& Small Business Management (7); Small Business Economics (2); International \\
& Journal of Entrepreneurial Behaviour and Research (3); International Journal of \\
& Entrepreneurship and Innovation (1); Journal of Family Business Strategy (1); Journal \\
& of Small Business and Enterprise Development; (13); Venture Capital (0); \\
& International Entrepreneurship and Management Journal (3); Journal of Enterprising \\
& Culture (2); Journal of Entrepreneurship (2); Journal of International \\
& Entrepreneurship (5); Journal of Small Business and Entrepreneurship (5); Social \\
& Enterprise (1); World Review of Entrepreneurship, Management, and Sustainable \\
& Development (0)
\end{tabular}

General Management, Academy of Management Journal (0); Academy of Management Review (0); Ethics, and Social Administrative Science Quarterly (0); Journal of Management (0); British Journal of Responsibility Management (2); Business Ethics Quarterly (0); Journal of Management Studies (0)

International Business Journal of International Business (0); Journal of World Business (0) and Area Studies

Marketing

Organization Studies Strategy
Journal of Consumer Psychology (0); Journal of Consumer Research (2); Journal of Marketing (3); Journal of Marketing Research (0); Marketing Science (1); International Journal of Research in Marketing (0); Journal of Retailing (0); Journal of the Academy of Marketing Science (0); European Journal of Marketing (8); Industrial Marketing Management (0); International Marketing Review (5); Journal of Advertising (0); Journal of Advertising Research (0); Journal of Interactive Marketing (0); Journal of International Marketing (5); Journal of Public Policy and Marketing (1); Marketing Letters (0); Marketing Theory (0); Psychology \& Marketing (0); Quantitative Marketing and Economics (0); Journal of Personal Selling and Sales Management (3)

Organization Science (0); Human Relations (0); Leadership Quarterly (0); Organization Studies (2); Organizational Research Methods (0); Organization (0); Group and Organization Management (0); Research in Organizational Behavior (0); Research in the Sociology of Organizations (0)

Strategic Management Journal (5)

${ }^{1}$ Including American Journal of Small Business

practices, or had no empirical grounding within an entrepreneurship setting. Examples included articles that discussed phenomena clearly relevant to selling, but not to entrepreneurship e.g. routinized selling of standardized products/services in an established multinational (Verhoef, 2003; Ulaga and Eggert, 2006; Chan et al., 2010). In reflection of the "contestable boundaries" (Zahra and Wright, 2011:68) of the entrepreneurship field, determining whether or not a 
particular article discussed a relevant 'entrepreneurial context' proved to be the most challenging exclusion criteria to assign. We aimed to be inclusive, only rejecting an article if it held no relevance for either selling or entrepreneurship. As a result, we incorporated articles where the empirical context was somewhat loosely 'entrepreneurial' (e.g. Darr and Pinch 2013 on selling at a market stall). Ultimately, an article was included if it met one of two conditions: 1) where the firms being examined in an article were 'new ventures' under 10 years of age, 2) where the authors themselves identified the context as involving 'entrepreneurship' or an 'entrepreneur'. Following exclusions, we compiled a final sample of 109 articles.

\subsection{Analysis}

We employed an inductive approach designed to organize the core subject matter of articles into higher-level classifications. Using our sample of articles as the 'data' (e.g. Thorpe et al., 2005), this process followed principles similar to those applied in qualitative 'open' coding methodologies (Gioia et al., 2013). We began by recording and classifying details such as methodological approach, unit of analysis, and theoretical underpinnings. We then developed descriptive accounts of the particular selling activities and activity-sets under examination within articles. Interpretations were determined through multiple in-depth manual readings of the source materials, which encouraged "context sensitive" (Tranfield et al., 2003: 219) consideration of phenomenon descriptors. Through an interactive and iterative process of discussion, our research team sought to develop a collective understanding (Macpherson and Holt, 2007) of entrepreneurship-selling intersections allowing the development of consistent primary and secondary themes that were tied to particular theoretical foundations and/or research approaches. We elected to code all relevant selling activities detailed within a given article, meaning that a single study could potentially address several entrepreneurshipselling intersections. The rationale for this was to avoid the application of overly restrictive classifications, thus encouraging fuller coverage of the topic. Where possible, phenomenon 
Figure 1 Analytical categorization

\begin{tabular}{|c|c|c|c|}
\hline $\begin{array}{l}\text { Aggregate } \\
\text { theme }\end{array}$ & $\begin{array}{l}2^{\text {nd }} \text { order } \\
\text { theme }\end{array}$ & $\begin{array}{l}1^{\text {st }} \text { order } \\
\text { theme }\end{array}$ & Theme description \\
\hline \multirow{3}{*}{ Antecedents \{} & $\begin{array}{c}\text { Resources \& } \\
\text { Characteristics }\end{array}$ & $\begin{array}{l}\text { Assets \& resources } \\
\text { Ascribed characteristics }\end{array}$ & $\begin{array}{l}\text { Physical, knowledge \& social resources possessed by the entrepreneurial entity } \\
\text { Ascribed characteristics of the entrepreneur (e.g. age, gender, ethnicity) }\end{array}$ \\
\hline & Strategic & Strategic orientation & Strategic commitment; market, customer \& entrepreneurial orientations \\
\hline & Positioning & Strategic decisions & Selection of target market segments; choice of market entry mode, pricing \\
\hline \multirow[t]{2}{*}{ Activities } & $\begin{array}{l}\text { Entrepreneur- } \\
\text { Customer } \\
\text { Interface }\end{array}$ & $\begin{array}{l}\text { Prospecting } \\
\text { Relationship governance } \\
\text { Relational co-creation } \\
\text { Sales work }\end{array}$ & $\begin{array}{l}\text { Networking activities used to identify and open channels with prospective customers } \\
\text { Activities associated with the management of entrepreneur-customer relationships } \\
\text { Opportunity co-creation conducted within entrepreneur-customer relationships } \\
\text { Micro-interactional exchanges between entrepreneurs \& customers }\end{array}$ \\
\hline & $\begin{array}{l}\text { Functional } \\
\text { Management }\end{array}$ & $\begin{array}{l}\text { Sales operation } \\
\text { System adoption } \\
\text { Sales staff management }\end{array}$ & $\begin{array}{l}\text { Firm level admin of sales function, design of sales process, information management } \\
\text { Implementation of operational and management systems (e.g. CRM systems) } \\
\text { Management, training, and incentivization of sales staff }\end{array}$ \\
\hline \multirow[b]{2}{*}{ Outcomes } & Economic & $\begin{array}{l}\text { Economic rents } \\
\text { Firm performance }\end{array}$ & $\begin{array}{l}\text { Generation of monetary return (revenue and/or profits) } \\
\text { Sales as indicator of organizational performance (firm growth, market share) }\end{array}$ \\
\hline & Non-economic & $\begin{array}{l}\text { Opportunity } \\
\text { Capabilities } \\
\text { Reputation }\end{array}$ & $\begin{array}{l}\text { Development of the entrepreneurial offering and/or the associated value proposition } \\
\text { Development of firm capabilities, knowledge transfer, entrepreneurial learning } \\
\text { Changes to individual/firm reputation, legitimacy, customer perceptions }\end{array}$ \\
\hline \multirow{3}{*}{ Context } & Setting & $\begin{array}{l}\text { Localized } \\
\text { Socio-economic } \\
\text { Virtual }\end{array}$ & $\begin{array}{l}\text { Specific localized settings and the social norms that govern them } \\
\text { The business, economic, social, political, and institutiional contexts of regional areas } \\
\text { E-commerce interfaces, online platforms, virtual communities }\end{array}$ \\
\hline & Offering & $\begin{array}{l}\text { Standardized } \\
\text { Customized }\end{array}$ & $\begin{array}{l}\text { Mass-produced off-the-shelf goods, commodities, standard services (e.g. hotel rooms) } \\
\text { Emerging technologies, bespoke solutions }\end{array}$ \\
\hline & $\begin{array}{l}\text { Customer } \\
\text { Type }\end{array}$ & $\begin{array}{l}\mathrm{B} 2 \mathrm{~B} \\
\mathrm{~B} 2 \mathrm{C}\end{array}$ & $\begin{array}{l}\text { Business-to-business clients, including dominant \& powerful customers } \\
\text { Customers as individuals or informal social/community groups }\end{array}$ \\
\hline
\end{tabular}

descriptors and thematic labels followed the terms used within the source literature. However, in some cases, more theoretically relevant, or current, labels subsumed terms that were initially derived from the literature. This was simply a by-product of the thematic aggregation process, and typically happened in cases where a research topic had progressed from older descriptive accounts to more robust and accepted theoretical language. As such, during coding consolidations, new labels were often applied retrospectively to previously analyzed articles.

Figure 1 (above) provides a visual representation of our analytical categorization process. The phenomena identified within our 109 articles are grouped into four aggregate dimensions: antecedents, activities, contexts and outcomes. 


\section{Findings}

\subsection{Selling antecedents}

A substantial proportion of new venture-focused sales research does not explore selling activities per se, but rather the influence that a range of individual, team, and firm-level antecedents have on selling activities (or associated sales outcomes). Our analysis distils two categories of sales-influencing antecedents:

\subsubsection{Resources and characteristics}

Strategy literature has long held that firm-level resource configurations play an important role in underpinning competitive advantages (Barney, 1991; Amit and Schoemaker, 1993). The same applies to research at the entrepreneurship-selling nexus, where theoretical perspectives such as the resource-based view (RBV) have been used to conceptualize links between resources, organizational capabilities, and sales behaviors. Studies identified by our review explored the possession of various physical, technological, and knowledge-based assets (e.g. Burgel, 2000; Zahra et al., 2003; Leiblein and Reuer, 2004; Morgan-Thomas and Jones, 2009), as well as social resources (e.g. Lechner et al., 2006; Prashantham, 2011; Yu et al., 2011), examining how these help firms to break into new, or grow existing, markets (often in the context of new venture internationalization). A number of studies also utilized theoretical perspectives such as human capital and the upper echelons theory to, similarly, conceptualize the entrepreneurial team (e.g. team member experience) as a sales-influencing resource (Burgel, 2000; Westhead et al., 2001; Marvel and Droege, 2010; Bjørnåli and Aspelund, 2012).

At an individual level, studies have focused on how personal characteristics impact upon selling. Bates (2002), for example, highlights the influence of gender, finding that female entrepreneurs in the US were comparatively less likely than males to be awarded government sales contracts. Other studies, meanwhile, have investigated the utilization of ethnicity within 
entrepreneur-customer interactions (Dyer and Ross, 2000; Prashantham, 2011; Altinay et al., 2014).

\subsubsection{Strategic positioning}

The literature has also associated a range of strategic antecedents with new venture sales behaviors. Strategic positioning refers, in one sense, to the overall orientations exhibited by entrepreneurial entities. Early research in this area explored the role of perceived ‘entrepreneurial attitudes' (Morris et al., 1990) - innovativeness, risk-taking, and proactiveness - or 'entrepreneurial' personal selling dispositions (Hill and Wright, 2000) within new venture marketing departments. More recently, scholars have advanced increasingly nuanced analyses of sales-relevant orientation types. Studies by Hakala and Kohtamäki (2010; 2011), O'Dwyer and Ledwith (2009), and Ruokonen et al (2008) for example, investigate the often complex relationships between entrepreneurial, customer, technological, and competitor orientations, linking these to evidence of market penetration.

For the most part, antecedent-focused literature positions selling within the wider purview of the strategic marketing mix; most notably in the context of new venture internationalization strategies. A number of studies, for example, underlined founder/manager strategic commitment to internationalization as a key moderator of successful foreign market

entry (Preece et al., 1999; Johnson, 2004; Khavul et al., 2010b; Wood et al., 2011). The international entrepreneurship literature also focuses on the specific strategic decisions encompassing market engagement; in particular, those concerning market selection and entry mode choice. Researchers have associated the penetration of international markets with various strategic approaches; for example, Morgan-Thomas and Jones (2009) and Hennart (2014) on target market diversification, Brouthers et al (2009) on market restriction in resource constrained exporting firms, and McNaughton (2002) on the selection of distribution channels. 


\subsubsection{Selling antecedents - discussion and implications}

It is notable that, across both categories, a majority of the literature positions sales as a measure of performance as opposed to an individual, social, or organizational activity (or set of activities). For the most part, studies identified by our review sought to develop correlations between certain antecedent proxy measures (e.g. R\&D spend, number of patents, years of founder experience, number of licensing agreements) and subsequent measures of sales outcome (e.g. sales revenues, percentage of international sales, speed of revenue growth). Thus, while some form of market engagement (i.e. selling) was a central theme within all articles, a significant portion of the literature, both conceptually and empirically, overlooked the actual doing of selling. Clearly, strategic and resource antecedents play important roles in influencing sales outcomes in new ventures; however, if we are to advance knowledge of selling-specific phenomena, there also appears to be a requirement for stronger conceptual linkages between antecedents and specific selling activities (e.g. accessing customers, presenting opportunities, negotiating interactions, building and managing relationships).

To achieve this, studies might look to modify their research designs, and, in particular, the nature of their research questions. Prior research suggests, for example, that entrepreneurs who possess industry-specific expertise are better equipped to exploit opportunities that are relevant to said expertise (Rauch and Rijsdijk, 2013). A study at the entrepreneurship-selling intersection, however, might ask: when engaging with customers, how, in what circumstances, and in what capacity do entrepreneurs apply such expertise? Do they use their prior expertise to foster trust amongst customers? Or as a means to manage relationships? Or even to achieve a better price? Similar questions could be asked of any individual characteristic, organizational capability, or strategic disposition. Our review did uncover some limited evidence of these forms of research enquiry. Altinay et al's (2014) study of customer trust judgements, for example, explicitly investigates the specific ways in which ethnic minority entrepreneurs 
utilize aspects of their cultural identity during selling exchanges. Such work notionally represents a more selling-relevant approach to examining antecedent influences.

There also appears to be significant scope for improving the ways in which antecedents are empirically operationalized, particularly with respect to mobilizing selling as an organizational capability. Our review found that studies often used somewhat blunt measures to operationalize capabilities (for example, R\&D spend used as a proxy for 'technological capability' by Zahra et al., 2003). This is problematic in two senses. Firstly, many of the

'capabilities' assessed throughout the literature were only very loosely associated with the selling function. Secondly, studies often utilized the terms 'resources' and 'capabilities' interchangeably (e.g. Zahra et al., 2003; Leiblein and Reuer, 2004), meaning that assessments of actual resource deployment were underplayed in favour of simply measuring the static possession of resources (see Amit and Schoemaker, 1993). Reflecting similar critiques noted in the strategy literature (e.g. Priem and Butler, 2001), studies of new ventures sales would likely benefit from more tailored operationalization of the features that underpin the sales function (see, for example, Gruber et al., 2010, as one of the few articles that attempts to assess specific configurations of organizational selling capabilities, as opposed to simply linking loosely related resource sets to sales behaviours).

\subsection{Selling activities}

Activities associated with selling in new ventures are varied in nature, and coverage is fragmented across extant literature. In many articles, selling forms an important aspect of the narrative arc, yet is not the core or even peripheral phenomenon being studied. This observation reflects the empirically prevalent, but under-conceptualized, status of sales in entrepreneurship research. Our analysis delineates two broad categories of selling activities. The first concerns phenomena constitutive of the entrepreneurial-customer interface, where prospective buyers are identified and negotiated with, and where relational exchanges are governed. The second 
concerns activities involved in the operation of the sales function, which largely explore selling as a firm-level operational activity.

\subsubsection{Entrepreneur-customer interface}

In order to sell their offerings, entrepreneurs (or those working for entrepreneurial ventures) are required to interact with customers. Our analysis distils a number of activities at the entrepreneur-customer interface.

One prominent research theme explores the efforts of entrepreneurs to identify and access customers. Such work serves to underline that customers do not exist in pre-defined groups, but rather that the 'customer' status emerges when entrepreneurs interact with certain external stakeholders. Research in this area builds largely on the concept of networking, typically positioning customer 'prospecting' as part of the broader challenges that new ventures face when attempting to gather external resources (e.g. Jarillo, 1989; Zhao and Aram, 1995; Lechner et al., 2006). Studies have, for example, placed focus on how entrepreneurs transition from 'personal contact' networks in order to access customers residing within wider 'outsider' networks (e.g. Ali, 1995; Jones and Rowley, 2011b). As Prashantham and Birkinshaw (2008) highlight in their examination of cross-border co-ethnic ties, this is often contingent upon entrepreneurs' use of social capital. Given, however, that new ventures characteristically face reputational and social capital deficiencies, scholars have found entrepreneurs are typically required to engage in practices that build credibility with prospective customers (Measson and Campbell-Hunt, 2015). The development of proxy relationships play an important role, notably with respect to how new ventures leverage customer-accessing social capital from relevant stakeholders, such as board members (Rehme and Svensson, 2011) and network gatekeepers (Gao et al., 2016), or through the utilization of reputation-enhancing interfaces e.g. online sales platforms (Reuber and Fischer, 2009). 
Assuming that customers have been identified, investigations into the act of selling itself have often been framed within the broader concept of relationship marketing (Dyer and Ross, 2000). Accordingly, studies have chiefly explored selling in terms of how entrepreneurs strategically govern, and leverage, customer 'exchange relationships' (e.g. Yli-Renko et al., 2001a; Fischer and Reuber, 2004; De Clercq and Rangarajan, 2008; Yli-Renko and Janakiraman, 2008; Chowdhury, 2011). We identify a number of reasons why examinations of relationship-oriented selling have been so prevalent throughout the new venture sales literature. First of all, strong relationships are seen as a source of competitive advantage for entrepreneurs (De Clercq and Rangarajan, 2008). Secondly, owing to resource deficiencies, new ventures are likely to be more commercially dependent on their customers (Raymond and St-Pierre, 2004), and thus more reliant on effective relationship management strategies in order to mitigate power disparities (Yli-Renko et al., 2001b; Fischer and Reuber, 2004; Yli-Renko and Janakiraman, 2008). Thirdly, customer relationships can act as important drivers of capability improvements in developing ventures (Yli-Renko et al., 2001a; De Clercq and Rangarajan, 2008; Perez et al., 2013).

The governance of sales relationships has been explored in two principal manners (see Fuller and Lewis, 2002, for a more detailed typology). On one hand, scholars have looked to practical, functional means of facilitating relational exchange; for example, the design of purchasing processes (Fischer and Reuber, 2004) or the synchronization of buyer-seller 'activity cycles' (Khavul et al., 2010a). Such measures typically require formalization of the customer interface (i.e. the use of explicit rules, programs, policies, and systems), which can support new ventures in managing customer-driven complexity (Chowdhury, 2011). Equally, formal contractual arrangements have also been cited as a means through which new ventures can "minimize external dependencies and protect themselves against opportunism" when dealing with more powerful customers (Yli-Renko et al., 2001b: 530). 
An alternative perspective sees the governance of sales relationships as rooted in a range of socio-psychological moderators, which influence the outcomes, and quality, of exchanges. Commonly recurring themes relate to the facilitating roles of trust, commitment, and loyalty (Prause et al., 2013); features that were associated with shared practice (Coviello and Joseph, 2012), intense tacit knowledge exchange (Darr and Talmud, 2003), and alignment of venture-customer perspectives (Dessì and Floris, 2010; Dessi et al., 2014). For those scholars who explore trust-based relational governance, the selling transaction itself typically represents just one aspect of these broader social exchanges (De Clercq and Rangarajan, 2008). Indeed, in most cases, customer interaction has been viewed as less about monetary exchange and more about the various non-economic practices that take place within partnerships e.g. learning alliances (Perez et al., 2013; Löfgren, 2014), value co-creation (Ngugi et al., 2010; Gurau and Duquesnois, 2011; Cossío Silva et al., 2013), and product co-development (Darr and Talmud, 2003; Coviello and Joseph, 2012).

While the literature has focused on the social moderators of exchanges, and on the strategic actions that govern them, there has been considerably less research attention paid to the observable social organization of sales interactions. Here, the entrepreneurship literature has advanced some (rather anecdotal) contributions; for example, 'storytelling' as a sales persuasion technique (Dyer, 2001). Other studies have conceptualized the role of informal social mechanisms e.g. going for dinner, gift giving, 'having a chat' (Zhao and Aram, 1995; Altinay et al., 2014). It is striking, however, that the overwhelming majority of entrepreneurship articles identified by our review mobilized the entrepreneur-customer exchange solely from the perspective of the entrepreneurial entity. This, of course, eliminates customer agency from the act of selling. A minority of other studies, conversely, empirically operationalized customer perspectives, but not those of the entrepreneur (e.g. Prause et al., 2013), thus again underplaying the significance of the interaction. Evidence of micro- 
interactional sales work instead emerged from studies that were somewhat tenuously associated with entrepreneurship; for example, Darr and Pinch's (2013) dramaturgical analysis of sales scripts at a market stall, Belk et al's (1988) examination of the social norms that govern selling at a 'swap-meet', and Friestad and Wright's (1994) conceptual model of customer 'persuasion knowledge'.

\subsubsection{Functional management}

Our analysis identified a varied corpus of research examining the intersection between entrepreneurial ventures and the functional management of sales activities. Studies in this category focused on firm-level considerations, particularly with respect to how new and developing ventures manage, or improve upon, the organizational mechanisms that underpin selling.

The general operation of the sales function was a theme that permeated a range of firmlevel studies within our review. In most cases, modifications to the sales function were cited as features of higher level strategies; for example, in Hennart's (2014) examination of business model design in 'born global' firms. Other studies, such as Song et al's (2010) work on formal processes for utilizing market information, were more explicit in emphasizing specific operational measures. Typically, discussions of firm-level selling practices were explored through the lens of the broader marketing function (e.g. Boag, 1987; Coviello et al., 2000; Hill and Wright, 2000) rather than being sales-specific in focus.

Amongst the most densely represented bodies of literature identified by our review were those studies that examined the adoption of specific systems to aid the selling function. Examples include the implementation of formal customer relationship management (CRM) systems (Cooper et al., 2005; Harrigan et al., 2009; Nguyen and Waring, 2013), loyalty card schemes (Hutchinson et al., 2015), information and communications technologies (Irvine and Anderson, 2008), and e-commerce platforms (Daniel et al., 2002; Moen, 2003; Dholakia and 
Kshetri, 2004; Simpson and Docherty, 2004; Bharadwaj and Soni, 2007; Moen et al., 2008; Madill and Neilson, 2010). The literature offers various rationales for the adoption of new systems; notably, the operational efficiency improvements that come with "routinization" of the sales function (Dholakia and Kshetri, 2004), as well as improvements to customer service (Harrigan et al., 2009), and the increased market reach afforded by a digital sales presence (Moen, 2003; Karagozoglu and Lindell, 2004).

While the literature sheds light on the prevalence of sales function systematization, or on managerial rationales for adoption (e.g. Bharadwaj and Soni, 2007; Irvine and Anderson, 2008), much of the research evidence focuses on descriptive accounts of the subject matter, and not on theorization of the underlying mechanics that characterize selling at the functional level. Even articles that notionally operationalize sales-specific functional activities typically do so through rather static assessments of strategic orientation (e.g. Khavul et al., 2010b) or organizational configuration (e.g. Gruber et al., 2010). While it is certainly useful to understand the components of new venture sales functions, extant research provides scant evidence of how these operate as a process, including, for example, how they change over time or in reaction to external stimuli.

Finally, studies that focus on firm-level selling also serve to remind us that, even in new ventures, frontline staff, rather than the entrepreneur-founder(s) themselves can act as the primary sales agent (e.g. Bonney and Williams, 2009). Emphasis here largely concerns general human resource management and work design with relevant research including studies of sales force training (Roman et al., 2002), reward and control systems (Spillecke and Brettel, 2014), feedback and goal-setting (Verdin, 1986), and the general management of independentlycontracted (Stanworth et al., 2004) or out-of-office (Yang and Kuo, 1996; McKague and Tinsley, 2012) sales staff. 


\subsubsection{Selling activities - discussion and implications}

Drawing on our findings, we identify a number of avenues for knowledge development at the entrepreneurship-selling intersection.

We argue, firstly, that scholars must seek to redress the overwhelmingly entrepreneurcentric focus of extant literature. Selling, whether in the form of a standalone transaction, or as part of a longer-term relationship, is inherently interactional. In-depth analysis of interaction content can therefore act as a necessary counterbalance to research that has treated selling as something of a 'hands-off' management activity. A progressive step here would be the empirical mobilization of both sides of sales exchanges, something that is evidently extremely rare in studies of new venture selling.

Second, we note a lack of research exploring how antecedents are made relevant and accountable during sales work. For example, looking to sociological and anthropological work on the use of socioeconomic class (Stern and Westphal, 2010) and even physical appearance (Mulford et al., 1998) through interaction, there is scope to address what have hitherto been taboo subjects for entrepreneurship scholars. Are better looking entrepreneurs able to exploit their looks to gain sales and resources? Do particular accents or dialects reveal details of social class or ethnic background that positively or negatively alter the trajectory of interactions? With recent evidence showing that such factors can exert significant influence on personal judgements, exemplified by Brooks et al's (2014) finding that investors favour pitches by attractive men, we propose a more systematic analyses of such factors can help entrepreneurship researchers unpick the social biases underpinning opportunity processes at the entrepreneurship-sales nexus.

We further contend that entrepreneurship research can benefit from selling scholars' focus on applied, practitioner knowledge. While we have previously noted this has been considered a weakness by some within the selling field (Plouffe et al., 2008), we argue that it 
is nonetheless an important strand of inquiry that could help make entrepreneurship research more relevant and valuable to knowledge users (Hermann and Landstrom, 2015). In particular, we note the Harvard Business Review special issue on selling from 2006 as an exemplar where insights from academic disciplines such as organizational psychology (Bonoma, 2006) and corporate governance (Anderson and Onyemah, 2006) were integrated with practitioner knowledge to answer a series of pressing manager-relevant questions.

Finally, given that emerging, or growing, entrepreneurial ventures often operate in a state of flux, cross-sectional analyses of functional sales activities are, we contend, of limited value to knowledge advancement. Instead, we encourage further investigation into the relationships between micro-interactional selling activities and the development of organizational sales systems. This would emphasize how entrepreneurs transition from early ad-hoc selling to more systematized firm-level approaches. Potential enquires might ask: how are technological or organizational customer interfaces designed in such a way that these support the entrepreneur's desired sales approach? Or, how do entrepreneurs embed and then crystalize the non-economic benefits resulting from sales interactions if employees are selling on their behalf?

\subsection{Outcomes of selling}

All reviewed articles either explicitly or implicitly identified certain outcomes that result from selling. Our analysis distinguishes economic and non-economic outcomes:

\subsubsection{Economic outcomes}

The principal outcome of selling identified throughout our review was the generation of economic rents. Given the inherent role that the realization of revenue (or profit) plays in both selling and entrepreneurship, this observation was unsurprising. For most of the literature, the rent-generating purpose of selling was simply referenced as part of an article's overall 
narrative. Others, meanwhile, explicitly mobilized sales revenue as their dependent variable, or a constituent aspect of their dependent variable; typically as some measure of firm performance e.g. increasing a market share (Leiblein and Reuer, 2004; Morgan-Thomas and Jones, 2009) or achieving firm growth (Reuber and Fischer, 2002; Hakala and Kohtamäki, 2010). Ultimately, every article in our sample, in some way, cited economic return and/or performance as a fundamental outcome of selling.

\subsubsection{Non-economic outcomes}

As our analysis of relational selling literature indicates, entrepreneur-customer interactions also facilitate various non-monetary benefits in new ventures. Perhaps the most fundamental of these concerns the role that customers can play in aiding the identification, evaluation, and refinement of entrepreneurial opportunities (Yli-Renko and Janakiraman, 2008; Rehme and Svensson, 2011). Studies have argued, for example, that customer interaction helps sellers to garner stronger understanding of a prospect's underlying business problems, thus supporting the development of more suitable solutions (Bonney and Williams, 2009). These findings chime with the wider notion of "value co-creation" (Cossío Silva et al., 2013), which sees experiential aspects of the sale being built into customer perceptions of an opportunity's value (Gurau and Duquesnois, 2011). Relational co-creation appears to play an especially important role in shaping innovation-oriented opportunities (see Ngugi et al., 2010; Perez et al., 2013; Löfgren, 2014). Coviello and Joseph's (2012) investigation into the codevelopment of major innovations exemplifies this theme, as does Darr and Talmud's (2003) study of tacit knowledge transfer in sales of emerging technology products.

Given that new ventures are often resource dependent, customer interaction can also act as a driver of capability development (Yli-Renko et al., 2001b; Fischer and Reuber, 2004; Yli-Renko and Janakiraman, 2008). Evidence suggests, for example, that the adoption of functional systems (e.g. ICT capacity, sales \& support systems) is primarily driven by customer 
demands (Fillis et al., 2004; Ngugi et al., 2010). Additionally, new ventures can build on customer resources to develop their own capabilities by proxy (Coviello and Joseph, 2012). Equally, customer dialogue can drive capability development through processes of knowledge exchange, information flow, and entrepreneurial learning (Yli-Renko et al., 2001a; Kristiansen et al., 2005; Lechner et al., 2006; De Clercq et al., 2010; Khavul et al., 2010b; Ruiz-Arroyo et al., 2012).

Finally, reputational improvements have also been cited as an outcome of selling (Chowdhury, 2011; Binz et al., 2013). On one hand, reputational transfer was viewed as a form of 'piggybacking', where entrepreneurial ventures leveraged legitimacy vicariously through their 'track record' associations with certain clients (Ali, 1995). This was a phenomenon often discussed in connection with 'powerful' customers (Yli-Renko et al., 2001b; Fischer and Reuber, 2004; Yli-Renko and Janakiraman, 2008). Other scholars cite more deliberate forms of advocacy, where clients aid entrepreneurial firms through direct referrals (Coviello and Joseph, 2012). For some researchers, reputational outcomes were heavily dependent on how 'close' venture-client relationships were (Chowdhury, 2011). However, Reuber and Fischer (2009) also show that, via firm-generated online 'signals', reputational enhancement can also occur within non-physical selling.

\subsubsection{Outcomes of selling - discussion and implications}

The basic function of selling is to generate economic returns from market offerings. Evidently, however, entrepreneur-customer interaction underpins a far wider range of outcomes, many of which are fundamental to new venture emergence and growth. Responding to recent calls for "a more interactive perspective of the entrepreneurial process" (Shepherd, 2015: 491), we see particular value in further study of how customers (or prospective customers) "contribute to the refinement of a potential opportunity". We contend that examination of the entrepreneurship-selling intersection offers unique perspectives on the 
influence of customer engagement during transformational periods such as opportunity emergence or firm growth transition (both of which pose fundamentally different research questions to studies of routinized sales in established firms). It is clear that research at the entrepreneurship-sales intersection sees selling not only as a medium for exploitation, but also for the identification, evaluation, and ongoing reshaping of opportunities. These processes, which appear to take place iteratively and concurrently rather than in distinctive sequential phases (see Corner and Ho, 2010), are also reflective of wider practitioner-led approaches; for example, Lean Startup (Ries, 2011) and the concept of Minimum Viable Product (MVP), which emphasize rapid prototyping, market testing, and experimentation cycles.

We further argue that there is significant scope for scholars to explore the impacts that customer exchanges have on venture development more generally. While this has clearly been a theme within the extant literature, much of the focus has remained on the measurement of capability changes in new ventures (e.g. Chowdhury, 2011). Building on our evidence of functional sales activities, we advocate further investigation into the actions associated with capability development in new ventures. Potentially promising avenues lie in practice-based approaches (e.g. Keating et al., 2014) and theorization at the intersection between dynamic capabilities and entrepreneurial learning (e.g. Zahra et al., 2006).

\subsection{Selling contexts}

The role of context in studies of entrepreneurship has been subject to vigorous debate in recent years (see Zahra, 2007; Welter, 2011; Zahra et al., 2014). We draw on our analysis of entrepreneurship-selling intersections to examine the range of contextual factors that impact new venture selling behaviors. 


\subsubsection{Sales setting}

The vast majority of studies that we analyzed did not provide detailed descriptions of the specific settings in which sales interactions took place. This was likely due to the nature of the research enquiries that dominated the literature, where scholars focused primarily on selling at a strategic or organizational level, and not at the level of individual exchanges. Nonetheless, some studies did serve to underline how material, social, or institutional contexts could influence sales dynamics.

For many, the impacts of place primarily stem from the norms that govern social exchanges in particular settings. From Measson and Campbell-Hunt's (2015) study of customer networking at an international trade show, to Viswanathan et al's (2012) examination of survivalist microenterprises in the South-Indian informal economy, each place possesses unique 'rules of the game' that can often become inextricably entangled with selling behaviors. Similar impacts were evident in studies that emphasized wider socioeconomic contexts. In highlighting, for example, poverty-alleviation benefits associated with microentrepreneurship, numerous studies have demonstrated the heavily interwoven nature of social order and market exchange in subsistence or informal marketplaces (Kristiansen et al., 2005; McKague and Tinsley, 2012; Viswanathan et al., 2012). Business culture also appears to play an important role, as evidenced by Sui's (2005) examination of relational marketing strategy variances in China, Hong Kong, and Taiwan.

There was a notable lack of research consideration, however, for how selling occurs in non-physical environments. Notionally, there may be scope to explore how buyers engage with technology-based purchasing processes or virtual communities. Attention was, however, largely limited to e-commerce as a market entry strategy (Moen, 2003; Arenius et al., 2005) or as an administrative facilitator of the sales function (Karagozoglu and Lindell, 2004; Bharadwaj and Soni, 2007). 


\subsubsection{Offering type}

The introduction of new market offerings represents a fundamental aspect of entrepreneurship. Evidence suggests that the nature of the offering can influence sales behaviors.

A prominent theme here concerned the extent of customization (or standardization) (Fischer and Reuber, 2004). The literature indicates, for example, that bespoke solutions (Bonney and Williams, 2009) and custom-made technologies (Darr and Talmud, 2003) typically require highly relational approaches to selling, which underpin efforts to develop shared understanding of an offering's function and value (Darr and Talmud, 2003; Coviello and Joseph, 2012). It is these forms of high-involvement selling that often, therefore, typify innovation-based new product introductions (Yli-Renko and Janakiraman, 2008). It is notable, however, that the vast majority of empirical studies in our review examined firms that possessed somewhat established offerings. The work of Rehme and Svensson (2011), as the only explicit study of 'first sales', stood out in this respect, stressing the additional challenges associated with selling an offering that is still under development.

In contrast, recognizable offerings such as food produce (Hill and Wright, 2000), hotel rooms (Irvine and Anderson, 2008), or other 'off the shelf' goods appeared to require little in the way of customer co-creation. In these cases, other aspects of the sale were typically emphasized. On one hand, these pertained to subjective elements of the customer purchasing experience; for example, how ventures cultivated personal relationships (Hill and Wright, 2000; Lindman, 2013; Altinay et al., 2014), or positive brand associations (Binz et al., 2013; Eggers et al., 2016). Offerings with a notable customer service element, where the purchasing experience melded together with customer perceptions of service experience as a whole, placed particular emphasis on these subjective, image-driven aspects of relational selling (Gurau and Duquesnois, 2011; Cossío Silva et al., 2013). On the other hand, sales of 'off the shelf' goods 
were also associated with the practical operational measures taken to ensure efficiency and reliability in purchasing processes (Fischer and Reuber, 2004). As a consequence, efforts to standardize elements of an offering frequently emerged as a means by which new ventures could automate the sales process, and, in turn, facilitate growth (Darr and Talmud, 2003; Chowdhury, 2011).

\subsubsection{Customer type}

While it was rare for studies of new venture selling to empirically mobilize customer agency, customer type was cited in a number of studies as an influential contextual variable. As outlined previously, 'dominant' customers raised unique considerations surrounding the management of power asymmetries (Yli-Renko et al., 2001b; Fischer and Reuber, 2004; Measson and Campbell-Hunt, 2015). On one hand, these discussions serve to highlight the transformational role that business-to-business (B2B) clients can play in new venture development (Yli-Renko and Janakiraman, 2008; Perez et al., 2013). On the other, however, they also highlight the increased risks associated with customer dependence (Raymond and StPierre, 2004).

Studies of business-to-customer (B2C) selling, conversely, placed little emphasis on the role of the customer as a development partner. As with sales of standardized offerings, the primary area of focus here was the transaction, particularly with respect to how customers made on-the-spot purchasing decisions based on perceived trustworthiness (Reuber and Fischer, 2009; Altinay et al., 2014) or social obligation (Viswanathan et al., 2012). Some potentially important observations can be made here. Firstly, discussions of relational selling to B2C customers (in terms of encouraging increased lifetime value through repeat business) were largely absent from the literature. Secondly, there were distinctive contrasts drawn between the typically direct purchasing authority possessed by B2C customers, and the more complex 
procurement procedures of organizational clients (Bates, 2002; Khavul et al., 2010a). Finally, it is notable that our analysis identified no studies of B2C selling that focused on either a) highgrowth oriented firms e.g. mass-market B2C selling, or b) sales of high-technology items.

\subsubsection{Selling contexts - discussion and implications}

The role of context has been underappreciated in management and organizational theory (Johns, 2006) and scholars are increasingly advocating for a more contextualized approach (Zahra, 2007; Welter, 2011; Zahra et al., 2014; Johns, 2017). Johns (2017: 577) describes context as "situational or environmental constraints and opportunities that have the functional capacity to affect the occurrence and meaning of organizational behavior". This is particularly relevant for scholars who elect to work at the entrepreneurship-selling nexus, where our review highlights the acontextual nature of many studies. A necessary step for more relevant entrepreneurship-selling theory therefore, may be to eschew a universalist approach and instead explore means of systematically embedding distal and proximal aspects of context into theory.

Various theories have achieved such an objective, including trait activation theory (Tett and Burnett, 2003), which examines relationships between personality, context, and the situational mediators that activate behaviors. Sillince (2007: 390) meanwhile argues "context may constitute a constraining structure for discourse, and yet it also provides space for agency", thus potentially providing a further framework through which to examine cross-context discursive work at the entrepreneurship-selling interface.

Our review highlights some preliminary contextual moderators at the entrepreneurshipselling nexus, including B2B versus B2C and first-sale versus routinized selling, though we stress there will be many more specific and nuanced contextual levers tied to each selling encounter that require deeper analysis. As Zahra and Wright (2011: 72) argue "entrepreneurial contexts exhibit considerable novelty, given that they are in the early stages of emergence" and 
accordingly, we suggest there is a need to explore methods for accessing these unpredictable, highly-fluid dynamics. One avenue may be to import approaches such as experience sampling methodology (Shiffman et al., 2008), which enables researchers to "capture dynamic personby-situation interactions as well as between- and within-person processes" with enhanced ecological validity (Uy et al., 2010: 31). Given the relative lack of empirical work that examines context, coupled with the aforementioned prevalence of static antecedent variables in extant research, such a development would be particularly welcome.

Finally, perhaps the greatest omission from our review was discussion of 'online' contexts. Online trade now accounts for a significant proportion of global sales transactions, yet there is little understanding of how the unique characteristics of online platforms shape interaction and communication in a new venture context. A study by McFarland and Ployhart (2015) provides an exemplary contextual framework for studying online communication (specifically social media) that may serve as inspiration for the development of more specific entrepreneurship-selling analyses. The authors (ibid: 1657) argue "social media represents extreme types of psychosocial contexts within which people interact and communicate that is different from other contexts". Hence, categorizing the discrete ambient stimuli that affect selling behavior through these media and other ecommerce platforms is necessary to understand emerging, disembodied forms of exchange.

\section{Discussion and theoretical implications}

Our objective in this review has been to develop a comprehensive, integrative understanding of the theoretical intersections connecting entrepreneurship and selling. We achieved this by undertaking a systematic analysis of the varied literatures that have, in some way, explored selling in an entrepreneurial context. Further to the research gaps and opportunities highlighted in the findings section, we will now consider how conceptual 
development of the entrepreneurship-selling interface can inform broader theoretical discussions within entrepreneurship theory.

\subsection{Contributions to theories of entrepreneurial opportunity}

One of most significant gaps in opportunity theory concerns the conceptualization of the mechanism(s) or process(es) through which opportunities become 'exploited' (Short et al., 2009; Godley, 2013). Furthermore, when scholars conceptualize exploitation as 'actionoriented' (de Jong, 2013), it encompasses such a wide range of activities - mobilizing and organizing resources (Sarason et al., 2006; Ketchen Jr et al., 2011); formulating and implementing strategies (Hmieleski and Baron, 2008); operating a business model (George and Bock, 2011) - that the granular details of market exchange are often glossed over. We believe this is a consequence of the taken for grantedness of markets as powerful institutions (Ahrne et al., 2015) in entrepreneurship scholarship, and the associated marginalization of the 'sales work' required to produce and reproduce these markets (Darr and Pinch, 2013).

In articles where the 'exchange' component of opportunity exploitation is addressed (e.g. Alvarez and Barney, 2007), it is rarely expanded upon or problematized, nor is it connected with many of the concepts or activities that we might recognize from our literaturederived framework. This suggests a fundamental disconnect between selling activities and entrepreneurship theory. Eckhardt and Shane (2003: 339), for example, argue that:

"In the process of the exploitation of opportunities, individuals acquire resources and engage in activities that change prices and provide information to others. The process of exchange and interaction provides information that increases the mutual awareness among market participants about the characteristics of the opportunity."

Although this description reflects some activities within our framework - most notably, the dynamic, interactive and market-altering nature of selling - the authors take a narrow and 
somewhat under-socialised economic perspective towards market exchange by focusing largely on information asymmetries and price. In doing so they fall short of capturing the conceptual richness and social complexity of the selling activities that are vital to economic exchange. This is significant, as selling interaction dynamics, and the skills and motivations of the individual entrepreneurial salesperson (such as persuasiveness and customer 'enchantment' e.g. Korczynski, 2005), can have an existential impact on whether an opportunity is exploited or not, perhaps even independent of any functional or logical product-market fit.

On undertaking this study, our expectation had been that a review of selling, as a fundamentally market-oriented activity, would address some of the aforementioned limitations with the opportunity exploitation construct. Evidence from our analysis makes it clear however, that selling activities have far broader implications for the ways that entrepreneurs and firms identify, create, evaluate, and refine opportunities - both during venture emergence and ongoing firm growth. In addition to the development of opportunities, exchanges with customers emerge as being vital to how entrepreneurial ventures develop the organizational capacity to deliver opportunities.

In summary, while a range of scholars have strongly, and with good reason, criticized the opportunity construct (Kitching and Rouse, 2016; Ramoglou and Tsang, 2016), we suggest that connecting extant opportunity theory to specific practices that constitute the microfoundations of entrepreneurship can improve theory development (Shepherd, 2015). We contend that our conceptualization of the entrepreneur-selling nexus can account for cases where creation, evaluation and, exploitation can happen synchronously within a single sales interaction, potentially offering a valuable window to studies of effectual entrepreneurship, which some (e.g. Arend et al., 2015; Arend et al., 2016) believe are lacking appropriate empirical validation. 


\subsection{Theorizing the customer in the entrepreneurship process}

The role of customers in shaping opportunities and co-creating value is an important one that has been covered extensively in marketing (Fernandes and Remelhe, 2016; Ranjan and Read, 2016) and innovation (von Hippel, 2005; Mahr et al., 2014) literatures. While entrepreneurship theory has previously adopted an opportunity co-creation perspective, largely through Sarasvathy's effectuation approach $(2001 ; 2003)$, we argue that the powerful agency of the customer remains critically under-theorized.

In Sarasvathy's (2001: 249) U-Haul vignette, for example, we are told "Shoen used processes of effectuation that involved his seizing and exploiting contingencies through an expanding network of human alliances". This initially sounds promising for understanding situated entrepreneurial selling; however, the activity is then reduced analytically to the following account: "He convinced friends, family members and customers (who then convinced others close to them, and so on) to individually make down payments on the trucks and then lend him the use of the trucks". Such an under-socialized approach to selling activities in relation to entrepreneurship theories is problematic (though not uncommon), as the tendency to treat the customer in both a theoretical and empirical sense as a passive, inert actor (how and through what means are they 'convinced' for example?), jars with both a common-sense knowledge of selling interactions and detailed empirical examples from our review that reveal the acute agency of buyers in a selling encounter. As economics without entrepreneurship is Hamlet without the Prince of Denmark (Baumol, 1968), so too then is entrepreneurship without a deeper conceptualization of the customer.

A growing number of scholars are calling for the entrepreneurship field to shift analytical focus from the entrepreneurial individual, towards entrepreneurs and their interactions with communities of interest (Shepherd, 2015) or 'stakeholders' (Wood and McKinley, 2010). However, following our review, we suggest that 'buyers' or 'customers' 
embody a unique social structural position that should not be so quickly homogenized into a general 'stakeholders' or 'communities' category alongside, for example, fellow entrepreneurs, investors, and suppliers. As our framework demonstrates, the customer occupies a unique role in market exchange processes that may overlap with - but never replicates - other actors in the entrepreneurial ecosystem. In the interest of theoretical clarity therefore, this distinction should be emphasized and explored further by scholars. In doing so, entrepreneurship scholars can extend upon marketing, selling and, organization studies literatures that afford the customer a greater, and in some cases even equal, analytical significance.

\subsection{Extending an entrepreneurship-as-practice approach to selling interactions}

Thus far we have situated our discussion within the dense layers of opportunity theory, and suggested our contribution may lie in relation to the impact our framework can have on established entrepreneurship scholarship. For our final discussion however, we highlight a different pathway, suggesting that scholars at the entrepreneurship-selling intersection may equally benefit from a more empirically-driven approach; one which examines the practices that constitute the doing of entrepreneurship (Clarke, 2011; Keating et al., 2014). An empiricist research agenda is desirable given that our systematic review identified a paucity of qualitative empirical or even descriptive accounts of sales work in entrepreneurial contexts. Unlike entrepreneurial opportunities, which some claim are elusive (see Dimov, 2011) and pose epistemological challenges stemming from the 'temporal collapse' which skews understanding of the sequential ordering of opportunity development and exploitation (Vogel, 2016), situated selling encounters necessitate human social interaction, which can be empirically accessed and observed by scholars (e.g. Llewellyn and Burrow, 2008).

Our review highlights a handful of papers that have taken such a reflexive interactionist approach to selling (e.g. Darr and Pinch, 2013), none of which were published in the entrepreneurship literature. We contend that insights from Garfinkel's (1967) 
ethnomethodology and Goffman's (1983) interaction order provide novel ways of examining the performative nature of sales work. Joining organization studies (Llewellyn and Spence, 2009), strategy (Whittington, 1996; Vaara and Whittington, 2012), and even selling scholars (Geiger and Kelly, 2014) who have begun to examine sales work through a social ontology (Schatzki, 2005), entrepreneurship scholars can adopt such perspectives to gain a deeper understanding of the embedded, socio-material practices that constitute, and are constitutive of, market exchanges (Ahrne et al., 2015). We conclude by suggesting that real-time naturalistic analysis of these selling interactions using video data (Clarke, 2011; Hindmarsh and Llewellyn, 2016; Zundel et al., 2016) can reveal deep layers of insight into the mutual organization and accomplishment of selling between entrepreneurs and their customers.

\section{Conclusions}

In this review, we have attempted to surface intersections between entrepreneurship and selling and hope to put 'selling' on the map as a focal topic of analysis for entrepreneurship scholars. We can only offer some speculative suggestions as to why selling has been largely absent from entrepreneurship theorizing, despite being intrinsic to the entrepreneurship process (Block and MacMillan, 1985). It may be that the neoclassical origins of entrepreneurship theory, or the emergence of strategic perspectives, have marginalized a more sociological understanding of selling. It may even be that scholars subconsciously view selling as mundane or lacking in prestige as a research subject, perhaps influenced by the often atheoretical nature of extant selling literature (Plouffe et al., 2008). In our article, we have attempted to address this issue by systematically auditing research evidence of selling phenomena in new venture contexts. We use this as a basis to argue that, in order to fully understand entrepreneurial opportunities, the entrepreneur-customer nexus where market exchange takes place must be fully integrated into the opportunity construct. Furthermore, we argue that selling encounters 
can provide a valuable empirical window into market exchanges in which exploitation occurs synchronously with opportunity shaping and evaluation.

Our study is not without limitations. While we made every effort to incorporate a broad range of selling literature, the parameters of our search necessarily excluded some potentially instructive research that focused solely on selling in 'non-entrepreneurial' contexts. We attempted to address this problem by incorporating concepts from the broader sales literature into our discussion sections.

Our conceptualization of entrepreneurial selling also provides some practical implications. Firstly, there are emerging critiques that 'selling' has been ignored as a topic by business schools, despite over $50 \%$ of US college graduates going on to do some form of salesbased job (Cespedes and Weinfurter, 2016). We believe this is particularly true of entrepreneurship courses, which are often centred on a relatively standard set of tools that typically include aspects of marketing, but not selling. A focus on start-up selling therefore, could significantly enhance the practical relevance of entrepreneurship education and overcome the lack of interest in selling reported by Deeter-Schmelz and Kennedy (2011). 


\section{Appendix A. Search procedure}

\section{A. Journal selection}

Journals selected from the following research field categories outlined by the Association of Business Schools (ABS) Academic Journal Quality Guide, Version 5:

a) Entrepreneurship and small business (all journals - 20)

b) General management, ethics, and social responsibility (all $4 *$ journals -7 )

c) International business and area studies (all $4 *$ journals -2 )

d) Marketing (all $3 *$ and $4 *$ journals, plus selected $2 *$ journal $^{1}-21$ )

e) Organization studies (all $4 *$ journals - 9)

f) Strategy (all $4 *$ journals - 1)

60 academic journals selected in total (see table.1 for further details).

B. Phase 1 search method

1. Search of articles within identified academic journals, using ABI, EBSCO, JSTOR, Proquest, Science Direct databases.

2. Search terms for entrepreneurship journals (title, abstract, keyword) ${ }^{2}$
a) Sale*
b) Sell*

3. Search terms for non-entrepreneurship journals = as above, but additionally filtered with the following secondary terms (full text):

- Entrepreneur*;

- Enterprise;

- Small/new/young AND business/firm/venture (all combinations);

- SME;

- Startup

C. Phase 2 search method

1. Manual reading of articles by three investigators, driving the development of broader search criteria based on expanded understanding of key concepts and phenomena

2. Search of articles conducted again using expanded search terms

3. Additional search terms for entrepreneurship journals (title, abstract, keyword)

a) Customer AND relation*3

b) Customer AND acquisition

\footnotetext{
${ }^{1}$ As the only sales-specific journal in the marketing field, we included the Journal of Personal Selling and Sales Management within our sample.

${ }^{2}$ Search results for entrepreneurship journals were restricted to articles published post-1985 in reflection of the sparse theoretical development that characterized the field's very early stages. We draw further on Hill and Wright, 2000, who similarly contest that selling has been a core feature of entrepreneurial marketing since 1985.

${ }^{3}$ We deliberately utilized word combinations rather than specific terms (in inverted commas) in order to pick up associated phrases such as "relationships with customers", "participation of customers", etc.
} 

c) Customer AND participation
d) Customer AND retention
e) Customer AND engagement
f) Co-creation AND customer
g) Cocreation AND customer
h) E-commerce
i) "Electronic Commerce"

4. Search terms for non-entrepreneurship journals $=$ as above, but additionally filtered with the following secondary terms (title, abstract, keyword):

- Entrepreneur*;

- Enterprise;

- Small/new/young AND business/firm/venture (all combinations);

- SME;

- Startup

\section{Appendix B. Exclusion procedure}

1. Exclusion categories created and applied independently by the three lead investigators for the initial 20 search hits

2. Collaborative discussion, cross-checking, and consolidation of exclusion criteria conducted by the three lead investigators

3. Process carried out for iterative 20 article cycles until the emergence of the following agreed exclusion labels:

a) No Market Actor: Articles that did not focus on entrepreneur or firm involvement with a market actor (i.e. a customer); for example, relationship management with competitors (Kuhn and Galloway, 2015), co-creation with institutions (Alvarez et al., 2015), discussions of general, rather than customer-specific, networking/participation, or where the entrepreneurial entity was the customer (Saparito et al., 2004; Morrissey and Pittaway, 2006);

b) Non-Entrepreneurship: Articles that discussed selling activities, but with no reference to entrepreneurship concepts and practices, or no empirical grounding within an entrepreneurship setting e.g. routinized selling of standardized products/services in an established multinational (Verhoef, 2003; Ulaga and Eggert, 2006; Chan et al., 2010)

c) Newness: articles that focused on ventures that were over 10 years old (where the information was available). We included articles where the age was not specified but the author(s) described actors as entrepreneurs.

d) Performance Measure: articles in which sales were discussed solely as a measurement of another phenomenon, typically as an indicator of firm growth;

e) No Theoretical Content: articles that placed no focus on theorizing, for example, book reviews, teaching cases, and associated explanatory notes; 
f) Non-Peer Reviewed: book chapters and other non-peer reviewed sources;

g) Commonly recurring Search Term Errors:

- Search terms were picked up within another word or phrase, or where they were used in a routine, everyday sense only;

- References to sale of firms rather than of products or services (e.g. Graebner and Eisenhardt, 2004), typically picked up through terms such as 'trade sale';

- General references to sales as a business function (typically 'Sales and Marketing') without any discussion regarding the activities involved in operating that function;

- References to "joint ventures" rather than new or small ventures.

\section{Appendix C. Coding and analysis procedure}

\section{A. Initial data organization}

Final sample of 109 accepted articles logged in an Excel workbook, recording the following information: Author name(s); Year of publication; Location of author(s) institution(s); Journal title; Data collection method and empirical context; Analysis approach; Unit of analysis; Core discussion; $1^{\text {st }}, 2^{\text {nd }}$, and aggregate codes; outcome descriptor(s); context descriptor(s).

\section{B. Thematic coding}

A manual coding procedure was employed whereby all three researchers individually read each article in-depth and followed the procedure detailed below:

1. A descriptive statement was developed to portray the primary phenomena(on) and key arguments outlined within an article;

2. A description of the primary theoretical underpinnings and main constructs were recorded in line with the terms used within an article;

3. A description was recorded to denote, a) the outcome(s) of selling activities, and b) the context(s) of selling activities;

4. Researchers met in 20 article cycles to discuss, cross-check, and consolidate these coding descriptions, resolving discrepancies and coming to agreements through discussion;

5. Through these discussions, researchers were able to assign relevant first-order coding labels to closely related and commonly recurring descriptive statements (as these coding labels became more familiar to the researchers, these were typically assigned simultaneously with descriptive statements);

6. In addition to discussing descriptive statements and conceptual underpinnings, crosschecking and consolidation meetings between the lead investigators now placed additional focus on examining and resolving discrepancies between first-order coding labels. Discussions were also held to assign labels to those descriptive statements that did not follow neatly within already identified categorizations;

7. This process was continued until all articles had a descriptive statement and agreed coding labels for: the primary phenomena(on), the theoretical/conceptual underpinnings, selling outcome(s); and sales context;

8. All articles in the sample were then rechecked through the frame of this coding scheme and further consolidations were made;

9. First order categories were consolidated into common thematic groups (see figure.1). 


\section{Appendix D. Description of sample}

\begin{tabular}{|c|c|c|c|c|c|}
\hline Author(s) & Year & Data Collection \& Empirical Context & Analysis & Theoretical/Literature Basis & Core Selling Discussion \\
\hline Ali & 1995 & $\begin{array}{l}\text { Qualitative Interviews (40 UK-based } \\
\text { previously unemployed individuals } \\
\text { turned entrepreneurs) }\end{array}$ & $\begin{array}{l}\text { Qualitative Analysis } \\
\text { (thematic coding) }\end{array}$ & $\begin{array}{l}\text { Network theory (weak \& } \\
\text { strong ties) }\end{array}$ & $\begin{array}{l}\text { The use of different networking approaches to } \\
\text { acquire early customers }\end{array}$ \\
\hline $\begin{array}{l}\text { Altinay, Saunders } \\
\text { \& Wang }\end{array}$ & 2014 & $\begin{array}{l}\text { Qualitative Interviews (134 UK-based, } \\
\text { Turkish-speaking ethnic minority } \\
\text { entrepreneurs) }\end{array}$ & $\begin{array}{l}\text { Qualitative Analysis } \\
\text { (thematic coding) }\end{array}$ & $\begin{array}{l}\text { "Cultural mosaics" / "cultural } \\
\text { tiles" }\end{array}$ & $\begin{array}{l}\text { The influence of culture on trust judgments in } \\
\text { customer relationships with ethnic minority } \\
\text { entrepreneurs }\end{array}$ \\
\hline $\begin{array}{l}\text { Arenius, Sasi \& } \\
\text { Gabrielsson }\end{array}$ & 2005 & $\begin{array}{l}\text { Single Case Study (longitudinal over } 4 \\
\text { years, } 12 \text { interviews with owners, } \\
\text { managers, employees, stakeholders; } \\
\text { informal emails/phone calls within } \\
\text { Finnish technology firm) }\end{array}$ & $\begin{array}{l}\text { Qualitative Analysis (reported } \\
\text { case) }\end{array}$ & $\begin{array}{l}\text { Resource-based view of the } \\
\text { firm; International } \\
\text { entrepreneurship }\end{array}$ & $\begin{array}{l}\text { Knowledge intensive firms using the Internet to } \\
\text { increase the speed of international sales }\end{array}$ \\
\hline Barker & 1985 & Conceptual & N/A & $\begin{array}{l}\text { Descriptive or subject-matter } \\
\text { specific }\end{array}$ & $\begin{array}{l}\text { Implementing a multistage salesforce } \\
\text { model in a small company }\end{array}$ \\
\hline Bates & 2002 & $\begin{array}{l}\text { Secondary Data Source (US Census - } \\
\text { women owned firms from a sample of } \\
40,000 \text { ) }\end{array}$ & $\begin{array}{l}\text { Quantitative Analysis } \\
\text { (logistic regression) }\end{array}$ & $\begin{array}{l}\text { Buyer discrimination; Power } \\
\text { asymmetries }\end{array}$ & $\begin{array}{l}\text { How gender (female) can negatively impact } \\
\text { ability to access sales opportunities (government } \\
\text { contracts) }\end{array}$ \\
\hline $\begin{array}{l}\text { Belk, Sherry Jr \& } \\
\text { Wallendorf }\end{array}$ & 1988 & $\begin{array}{l}\text { Single case ethnography (participant } \\
\text { observation, video, interviews with } \\
\text { consumers, sellers, regulators, managers } \\
\text { at a US 'swap meet') }\end{array}$ & $\begin{array}{l}\text { Qualitative Analysis } \\
\text { (thematic coding) }\end{array}$ & $\begin{array}{l}\text { Descriptive or subject-matter } \\
\text { specific }\end{array}$ & $\begin{array}{l}\text { Localised social \& structural rules, } \& \text { their } \\
\text { influence on the nature } \& \text { running of the sales } \\
\text { context }\end{array}$ \\
\hline $\begin{array}{l}\text { Bharadwaj \& } \\
\text { Soni }\end{array}$ & 2007 & $\begin{array}{l}\text { Survey (368 US-based SMEs, plus } 12 \\
\text { unstructured qualitative interviews with } \\
\text { businesses deemed successful at e- } \\
\text { commerce) }\end{array}$ & $\begin{array}{l}\text { Mixed Analysis (logistic } \\
\text { regression \& supplementary } \\
\text { case descriptions). }\end{array}$ & $\begin{array}{l}\text { Descriptive or subject-matter } \\
\text { specific }\end{array}$ & How \& why SMEs use e-commerce \\
\hline $\begin{array}{l}\text { Binz, Hair, Pieper } \\
\text { \& Baldauf }\end{array}$ & 2013 & Survey (253 Swiss consumers) & $\begin{array}{l}\text { Quantitative Analysis } \\
\text { (covariance-based structural } \\
\text { equation) }\end{array}$ & $\begin{array}{l}\text { Organizational/corporate } \\
\text { reputation; Family firms; } \\
\text { Customer preferences }\end{array}$ & $\begin{array}{l}\text { Promotion of a company's status as a family firm } \\
\text { to strengthen consumer preference }\end{array}$ \\
\hline $\begin{array}{l}\text { Bjørnåli \& } \\
\text { Aspelund }\end{array}$ & 2012 & $\begin{array}{l}\text { Survey (CEOs of } 109 \text { Norwegian } \\
\text { university spinouts) }\end{array}$ & $\begin{array}{l}\text { Quantitative Analysis } \\
\text { (hierarchical logistic } \\
\text { regression) }\end{array}$ & $\begin{array}{l}\text { RBV; Upper Echelons } \\
\text { perspective; Organizational } \\
\text { legitimacy; International } \\
\text { entrepreneurship }\end{array}$ & $\begin{array}{l}\text { Entrepreneurial management team member \& } \\
\text { director experience associated with acquisition of } \\
\text { sales from international customers }\end{array}$ \\
\hline Boag & 1987 & $\begin{array}{l}\text { Qualitative Interviews (marketing } \\
\text { executives in } 20 \text { Canadian 'early growth' }\end{array}$ & $\begin{array}{l}\text { Mixed analysis (assessment } \\
\text { of a priori categories) }\end{array}$ & Strategic marketing & $\begin{array}{l}\text { The development of marketing control systems } \\
\text { and operation of the sales process in SMEs }\end{array}$ \\
\hline
\end{tabular}




\begin{tabular}{|c|c|c|c|c|c|}
\hline & & $\begin{array}{l}\text { high technology firms; plus secondary } \\
\text { performance data) }\end{array}$ & & & \\
\hline $\begin{array}{l}\text { Bonney \& } \\
\text { Williams }\end{array}$ & 2008 & Conceptual & $\mathrm{N} / \mathrm{A}$ & Opportunity theory & $\begin{array}{l}\text { The role of salespeople in opportunity } \\
\text { identification }\end{array}$ \\
\hline $\begin{array}{l}\text { Brettel, Engelen, } \\
\text { Muller \& Schilke }\end{array}$ & 2010 & Survey (execs in 330 German startups) & $\begin{array}{l}\text { Quantitative Analysis } \\
\text { (logistic regression) }\end{array}$ & $\begin{array}{l}\text { Transaction cost economics; } \\
\text { Customer relationship \& } \\
\text { strategy literature }\end{array}$ & $\begin{array}{l}\text { Distribution channel choices of new } \\
\text { entrepreneurial ventures }\end{array}$ \\
\hline $\begin{array}{l}\text { Brouthers, Nakos, } \\
\text { Hadjimarcou \& } \\
\text { Brouthers }\end{array}$ & 2009 & $\begin{array}{l}\text { Survey (119 Greek \& } 83 \text { Caribbean small } \\
\text { internationalizing firms) }\end{array}$ & $\begin{array}{l}\text { Quantitative Analysis } \\
\text { (multiple regression) }\end{array}$ & $\begin{array}{l}\text { International } \\
\text { entrepreneurship; } \\
\text { Organizational Learning }\end{array}$ & $\begin{array}{l}\text { Emphasizing international sales while restricting } \\
\text { exports to a few foreign markets results in } \\
\text { superior international sales performance }\end{array}$ \\
\hline Burgel \& Murray & 2000 & $\begin{array}{l}\text { Survey ( } 398 \text { export decisions taken in } \\
246 \text { UK-based internationalizing } \\
\text { technology startups) }\end{array}$ & $\begin{array}{l}\text { Quantitative Analysis } \\
\text { (multiple regression) }\end{array}$ & International entrepreneurship & $\begin{array}{l}\text { The determinants of different entry modes into } \\
\text { international markets e.g. experience of } \\
\text { management team, R\&D capacity of firm, firm } \\
\text { size, innovativeness of technology }\end{array}$ \\
\hline Cassar & 2010 & Survey (830 nascent entrepreneurs) & $\begin{array}{l}\text { Quantitative Analysis (GMM } \\
\text { regression) }\end{array}$ & $\begin{array}{l}\text { Descriptive or subject-matter } \\
\text { specific }\end{array}$ & $\begin{array}{l}\text { Entrepreneur over-optimism when forecasting } \\
\text { initial \& early sales volumes }\end{array}$ \\
\hline Chia-Hung \& Liu & 2010 & $\begin{array}{l}\text { Big Data analytics (Taiwanese buyers on } \\
\text { online auction websites) }\end{array}$ & $\begin{array}{l}\text { Quantitative Analysis (least } \\
\text { squares regression; spline } \\
\text { regression) }\end{array}$ & Information asymmetries & $\begin{array}{l}\text { Seller reputation and impacts on online auction } \\
\text { prices }\end{array}$ \\
\hline Chowdhury & 2011 & $\begin{array}{l}\text { Survey } \& \text { archival data (134 US-based } \\
\text { young IPO firms) }\end{array}$ & $\begin{array}{l}\text { Quantitative Analysis } \\
\text { (logistic regression) }\end{array}$ & $\begin{array}{l}\text { Customer-driven complexities } \\
\text { in young firms }\end{array}$ & $\begin{array}{l}\text { Management of close customer relationships \& } \\
\text { associations with firm performance }\end{array}$ \\
\hline $\begin{array}{l}\text { Cooper, Upton \& } \\
\text { Seaman }\end{array}$ & 2005 & $\begin{array}{l}\text { Survey (452 execs compared in family } \& \\
\text { non-family firms) }\end{array}$ & $\begin{array}{l}\text { Quantitative Analysis } \\
\text { (Multinomial logit model) }\end{array}$ & $\begin{array}{l}\text { Customer relationship } \\
\text { management }\end{array}$ & Use of CRM in family \& non-family firms \\
\hline $\begin{array}{l}\text { Cossío Silva, } \\
\text { Revilla Camacho } \\
\text { \& Vega Vázquez }\end{array}$ & 2013 & $\begin{array}{l}\text { Survey ( } 547 \text { Spanish entrepreneurs \& } \\
\text { microenterprises in hairdressing personal } \\
\text { care services) }\end{array}$ & $\begin{array}{l}\text { Quantitative Analysis (Latent } \\
\text { class segmentation) }\end{array}$ & Value co-creation & $\begin{array}{l}\text { Value co-creation between microenterprises \& } \\
\text { customers }\end{array}$ \\
\hline $\begin{array}{l}\text { Coviello \& } \\
\text { Joseph }\end{array}$ & 2012 & $\begin{array}{l}\text { Multiple Case Study ( } 6 \text { cases exploring } \\
\text { major innovation development in tech- } \\
\text { based ventures, inc. interviews with firm } \\
\text { informants; email follow ups; archival } \\
\text { data) }\end{array}$ & $\begin{array}{l}\text { Qualitative Analysis } \\
\text { (thematic coding) }\end{array}$ & $\begin{array}{l}\text { Marketing; Innovation co- } \\
\text { creation }\end{array}$ & $\begin{array}{l}\text { Integrating customers into opportunity } \\
\text { development }\end{array}$ \\
\hline $\begin{array}{l}\text { Coviello, Brodie } \\
\& \text { Munro }\end{array}$ & 2000 & $\begin{array}{l}\text { Mixed method (survey of managers in } \\
302 \text { firms attending executive courses in } \\
\text { New Zealand \& Canada) }\end{array}$ & $\begin{array}{l}\text { Mixed methods (regression \& } \\
\text { content analysis of qualitative } \\
\text { data) }\end{array}$ & $\begin{array}{l}\text { Marketing; Entrepreneurial } \\
\text { Marketing }\end{array}$ & $\begin{array}{l}\text { How does firm size influence customer } \\
\text { relationships \& selling practices? }\end{array}$ \\
\hline $\begin{array}{l}\text { Daniel, Wilson \& } \\
\text { Myers }\end{array}$ & 2002 & Survey (678 UK-based SMEs) & $\begin{array}{l}\text { Quantitative Analysis (Cluster } \\
\text { analysis. Chi Square) }\end{array}$ & $\begin{array}{l}\text { Descriptive or subject-matter } \\
\text { specific }\end{array}$ & $\begin{array}{l}\text { The use of ICT to provide information, improve } \\
\text { service quality, \& to act as a sales \& marketing } \\
\text { interface }\end{array}$ \\
\hline
\end{tabular}




\begin{tabular}{|c|c|c|c|c|c|}
\hline Darr \& Pinch & 2013 & $\begin{array}{l}\text { Ethnography ( } 60 \text { hours of videos, } \\
\text { participant observation, \& } 25 \text { interviews } \\
\text { detailing Exchanges in UK-based open } \\
\text { market traders dealing in mass-produced } \\
\text { consumer items) }\end{array}$ & $\begin{array}{l}\text { Qualitative Analysis } \\
\text { (thematic coding of } \\
\text { interaction 'transition points') }\end{array}$ & $\begin{array}{l}\text { Sales work; Socio-materiality; } \\
\text { Ethnomethodology }\end{array}$ & $\begin{array}{l}\text { Social organisation of sales interactions. } \\
\text { Considers the role of social obligation \& how this } \\
\text { allows sellers \& buyers to move from one stage } \\
\text { of a sales encounter to the next. }\end{array}$ \\
\hline Darr \& Talmud & 2003 & $\begin{array}{l}\text { Comparative Case Study (interviews \& } \\
\text { communication content between buyer- } \\
\text { seller networks in } 2 \text { US-based technology } \\
\text { SMEs) }\end{array}$ & $\begin{array}{l}\text { Qualitative Analysis } \\
\text { (thematic coding) }\end{array}$ & $\begin{array}{l}\text { Network theory; Tacit } \\
\text { knowledge exchange }\end{array}$ & $\begin{array}{l}\text { How sellers overcome information asymmetries } \\
\text { with customers when attempting to sell emergent } \\
\text { technology products }\end{array}$ \\
\hline $\begin{array}{l}\text { De Clercq \& } \\
\text { Rangarajan }\end{array}$ & 2008 & $\begin{array}{l}\text { Survey ( } 217 \text { Western European } \\
\text { entrepreneurs, plus 6-month follow-up } \\
\text { survey) }\end{array}$ & $\begin{array}{l}\text { Quantitative Analysis (partial } \\
\text { least squares regression) }\end{array}$ & Social exchange theory & $\begin{array}{l}\text { Entrepreneurs' perceived relational support in } \\
\text { their relationships with customers }\end{array}$ \\
\hline Dessi \& Floris & 2010 & $\begin{array}{l}\text { Single Case Study (interviews with } 120 \\
\text { customers an Italian family firm) }\end{array}$ & Quantitative Analysis & $\begin{array}{l}\text { Perspective concordance; } \\
\text { Tacit knowledge exchange }\end{array}$ & $\begin{array}{l}\text { Relationships between management perceptions } \\
\text { of business strengths \& customer beliefs }\end{array}$ \\
\hline $\begin{array}{l}\text { Dessi, Ng, Floris, } \\
\& \text { Cabras }\end{array}$ & 2014 & $\begin{array}{l}\text { Multiple Case Study (interviews with } \\
\text { senior managers; survey of } 100 \\
\text { customers in } 2 \text { family owned \& two } \\
\text { larger Italian businesses) }\end{array}$ & Quantitative Analysis & $\begin{array}{l}\text { Knowledge management } \\
\text { perspective of CRM }\end{array}$ & $\begin{array}{l}\text { The role of tacit knowledge in dictating firm- } \\
\text { customer perceptions of relationship }\end{array}$ \\
\hline $\begin{array}{l}\text { Dholakia \& } \\
\text { Kshetri }\end{array}$ & 2004 & $\begin{array}{l}\text { Survey (45 US-based SMEs, mixed } \\
\text { industries) }\end{array}$ & $\begin{array}{l}\text { Quantitative Analysis } \\
\text { (logistic regression) }\end{array}$ & $\begin{array}{l}\text { Descriptive or subject-matter } \\
\text { specific }\end{array}$ & $\begin{array}{l}\text { Factors influencing the adoption of the internet as } \\
\text { a sales interface \& its role in enhancing a firm's } \\
\text { market reach \& operational efficiency through } \\
\text { 'routinization' }\end{array}$ \\
\hline Dyer \& Ross & 2000 & $\begin{array}{l}\text { Qualitative Interviews ( } 33 \text { semi } \\
\text { structured interviews of Canadian black } \\
\text { owner-managers) }\end{array}$ & $\begin{array}{l}\text { Qualitative Analysis } \\
\text { (thematic coding) }\end{array}$ & $\begin{array}{l}\text { Ethnic-minority } \\
\text { entrepreneurship }\end{array}$ & $\begin{array}{l}\text { Network relationships between ethnic minority } \\
\text { businesses \& their co-ethnic clients }\end{array}$ \\
\hline $\begin{array}{l}\text { Eggers, Eggers \& } \\
\text { Krause }\end{array}$ & 2016 & $\begin{array}{l}\text { Experimental design (perceptions of } 113 \\
\text { potential target customers) }\end{array}$ & $\begin{array}{l}\text { Experimental design (Choice- } \\
\text { based conjoint analysis) }\end{array}$ & Entrepreneurial branding & $\begin{array}{l}\text { The characteristics that signal that an } \\
\text { entrepreneurs' brand is trustworthy }\end{array}$ \\
\hline $\begin{array}{l}\text { Fillis, Johansson } \\
\text { \& Wagner }\end{array}$ & 2004 & $\begin{array}{l}\text { Qualitative Interviews ( } 21 \\
\text { owner/managers of Scottish SMEs) }\end{array}$ & $\begin{array}{l}\text { Qualitative Analysis } \\
\text { (thematic coding) }\end{array}$ & $\begin{array}{l}\text { Descriptive or subject-matter } \\
\text { specific }\end{array}$ & $\begin{array}{l}\text { Customer role in driving e-commerce adoption in } \\
\text { SMEs }\end{array}$ \\
\hline Fischer \& Reuber & 2004 & $\begin{array}{l}\text { Qualitative Interviews (27 CEOs in } \\
\text { Canadian high growth ventures) }\end{array}$ & $\begin{array}{l}\text { Qualitative Analysis } \\
\text { (grounded open coding) }\end{array}$ & $\begin{array}{l}\text { Resource dependence } \\
\text { perspective; Relational } \\
\text { perspective }\end{array}$ & $\begin{array}{l}\text { Discusses tactics for governing or offsetting } \\
\text { disparities in relationships with dominant } \\
\text { customer in a range of competitive contexts. }\end{array}$ \\
\hline Friestad \& Wright & 1994 & Conceptual & N/A & $\begin{array}{l}\text { Persuasion knowledge } \\
\text { (consumer behaviour) }\end{array}$ & $\begin{array}{l}\text { The nature \& development of persuasion } \\
\text { knowledge \& how people use it to interpret, } \\
\text { evaluate, \& respond to influence attempts from } \\
\text { salespeople. }\end{array}$ \\
\hline
\end{tabular}




\begin{tabular}{|c|c|c|c|c|c|}
\hline Fuller \& Lewis & 2002 & $\begin{array}{l}\text { Qualitative Interviews (36 } \\
\text { owner/managers of UK SMEs) }\end{array}$ & $\begin{array}{l}\text { Qualitative Analysis } \\
\text { (grounded open coding) }\end{array}$ & $\begin{array}{l}\text { Networks, structure/agency, } \\
\text { ethnomethodology }\end{array}$ & $\begin{array}{l}\text { Market exchange activities are reflexively shaped } \\
\text { by interactions with customers }\end{array}$ \\
\hline $\begin{array}{l}\text { Gao, Ren, Zhang } \\
\& \text { Sun }\end{array}$ & 2016 & Single Case Study & $\begin{array}{l}\text { Qualitative Analysis (Critical } \\
\text { incident technique) }\end{array}$ & Networks; Structural holes & $\begin{array}{l}\text { The role of network gatekeepers in international } \\
\text { market entry }\end{array}$ \\
\hline Gibb Dyer JR & 2001 & $\begin{array}{l}\text { Historic overview of US Network } \\
\text { Marketing industry }\end{array}$ & Illustrative case & $\begin{array}{l}\text { Descriptive or subject-matter } \\
\text { specific }\end{array}$ & Storytelling as a sale persuasion device. \\
\hline $\begin{array}{l}\text { Gruber, } \\
\text { Heinemann, } \\
\text { Brettel \& } \\
\text { Hungeling }\end{array}$ & 2010 & $\begin{array}{l}\text { Survey ( } 230 \text { German technology } \\
\text { ventures) }\end{array}$ & $\begin{array}{l}\text { Quantitative Analysis (PLS, } \\
\text { structural equation modeling } \\
\text { \& cluster analysis) }\end{array}$ & $\begin{array}{l}\text { Resource-based view of the } \\
\text { firm; Resource } \\
\text { configurations; } \\
\text { Organizational capabilities }\end{array}$ & $\begin{array}{l}\text { Configuration \& capability function within Sales } \\
\& \text { Distribution departments }\end{array}$ \\
\hline $\begin{array}{l}\text { Gurau \& } \\
\text { Duqusnois }\end{array}$ & 2011 & $\begin{array}{l}\text { Document \& website analysis of } 102 \\
\text { French wine producers }\end{array}$ & $\begin{array}{l}\text { Qualitative Analysis (reported } \\
\text { cases) }\end{array}$ & $\begin{array}{l}\text { Value co-creation; } \\
\text { Relationship marketing; } \\
\text { Service dominant logic }\end{array}$ & $\begin{array}{l}\text { Value creation between seller \& customer } \\
\text { through online marketing approaches }\end{array}$ \\
\hline $\begin{array}{l}\text { Hakala \& } \\
\text { Kohtamaki }\end{array}$ & 2010 & Survey (164 Finnish software SMEs) & $\begin{array}{l}\text { Quantitative Analysis (partial } \\
\text { least squares regression) }\end{array}$ & $\begin{array}{l}\text { Customer orientation; } \\
\text { entrepreneurial orientation }\end{array}$ & $\begin{array}{l}\text { Interplay between entrepreneurial, technology \& } \\
\text { customer orientations \& firm performance }\end{array}$ \\
\hline $\begin{array}{l}\text { Hakala \& } \\
\text { Kohtamaki }\end{array}$ & 2011 & Survey (164 Finnish software SMEs) & $\begin{array}{l}\text { Quantitative Analysis (non- } \\
\text { hierarchical cluster analysis) }\end{array}$ & $\begin{array}{l}\text { Customer orientation; } \\
\text { entrepreneurial orientation }\end{array}$ & $\begin{array}{l}\text { Technology firms combining several strategic } \\
\text { orientations perform better than those focusing } \\
\text { solely on customer orientation }\end{array}$ \\
\hline $\begin{array}{l}\text { Harrigan, Ramsey } \\
\text { \& Ibbotson }\end{array}$ & 2009 & $\begin{array}{l}\text { Survey (286 Northern Irish \& Irish } \\
\text { SMEs) }\end{array}$ & $\begin{array}{l}\text { Quantitative Analysis } \\
\text { (univariate \& bivariate } \\
\text { analyses) }\end{array}$ & $\begin{array}{l}\text { Electronic-customer } \\
\text { relationship management (e- } \\
\text { CRM) }\end{array}$ & $\begin{array}{l}\text { The role of internet technologies in customer } \\
\text { relationship management activities }\end{array}$ \\
\hline Hennart & 2014 & Historic case study & Illustrative case & International entrepreneurship & $\begin{array}{l}\text { Market selection \& product offering (spatially } \\
\text { dispersed customers distinctive niche products } \\
\text { that incur low communication, transportation, \& } \\
\text { adaptation costs) \& links to early international } \\
\text { sales. }\end{array}$ \\
\hline Hill \& Wright & 2000 & $\begin{array}{l}\text { Qualitative Interviews (63 interviews } \\
\text { with } 54 \text { SMEs in UK agri-food sector) }\end{array}$ & $\begin{array}{l}\text { Qualitative Analysis (reported } \\
\text { case) }\end{array}$ & $\begin{array}{l}\text { Entrepreneurial Marketing; } \\
\text { Entrepreneurial Orientation }\end{array}$ & $\begin{array}{l}\text { The relationship between entrepreneurial \& } \\
\text { marketing orientations. An entrepreneurial } \\
\text { orientation manifests itself in a strong personal } \\
\text { selling focus. }\end{array}$ \\
\hline $\begin{array}{l}\text { Hutchinson, } \\
\text { Donnell, Gilmore } \\
\text { \& Reid }\end{array}$ & 2014 & $\begin{array}{l}\text { Single Case Study (longitudinal in UK } \\
\text { retail SME) }\end{array}$ & $\begin{array}{l}\text { Qualitative Analysis } \\
\text { (thematic coding) }\end{array}$ & Marketing Management & $\begin{array}{l}\text { Loyalty card adoption in SME retailers \& impact } \\
\text { upon marketing management }\end{array}$ \\
\hline $\begin{array}{l}\text { Ingenbleek \& van } \\
\text { der Lans }\end{array}$ & 2010 & $\begin{array}{l}\text { Survey ( } 95 \text { manufacturing } \& \text { service } \\
\text { SMEs in The Netherlands) }\end{array}$ & $\begin{array}{l}\text { Quantitative Analysis } \\
\text { (Confirmatory factor analysis) }\end{array}$ & $\begin{array}{l}\text { Strategic marketing planning } \\
\text { theory }\end{array}$ & Price setting in SMEs \\
\hline $\begin{array}{l}\text { Irvine \& } \\
\text { Anderson }\end{array}$ & 2007 & $\begin{array}{l}\text { Mixed (Survey of } 93 \text { founders in rural } \\
\text { Scottish hotels; plus } 10 \text { in-depth } \\
\text { interviews) }\end{array}$ & $\begin{array}{l}\text { Mixed Analysis (descriptive } \\
\text { statistics, frequency analysis, } \\
\text { Pearson chi-square tests, } \\
\text { Pragmatic Content Analysis) }\end{array}$ & $\begin{array}{l}\text { Descriptive or subject-matter } \\
\text { specific }\end{array}$ & $\begin{array}{l}\text { The use of ICT to provide information, improve } \\
\text { service quality, \& to act as a sales \& marketing } \\
\text { interface in rural firms. }\end{array}$ \\
\hline Jarillo & 1989 & $\begin{array}{l}\text { Secondary Data Source (Database of over } \\
5000 \text { US firms) }\end{array}$ & $\begin{array}{l}\text { Quantitative Analysis } \\
\text { (logistic regression) }\end{array}$ & $\begin{array}{l}\text { Descriptive or subject-matter } \\
\text { specific }\end{array}$ & $\begin{array}{l}\text { The use of personal relationships to obtain } \\
\text { "insider" sales. }\end{array}$ \\
\hline
\end{tabular}




\begin{tabular}{|c|c|c|c|c|c|}
\hline Johnson & 2004 & $\begin{array}{l}\text { Mixed ( } 12 \text { interviews \& } 191 \text { respondent } \\
\text { survey of executives in US \& UK } \\
\text { internationalizing high-tech firms) }\end{array}$ & $\begin{array}{l}\text { Mixed analysis (qualitatively } \\
\text { identifies influential factors \& } \\
\text { quantitatively measures } \\
\text { importance of } 25 \\
\text { internationalization factors) }\end{array}$ & International entrepreneurship & $\begin{array}{l}\text { The international vision of the founders \& the } \\
\text { possession of international contacts/sales leads } \\
\text { influence early international customer acquisition } \\
\text { in SMEs. }\end{array}$ \\
\hline Jones \& Rowley & 2011 & $\begin{array}{l}\text { Single Case Study (longitudinal with } \\
\text { participant-observation, desk research, \& } \\
\text { interviews with owner-managers \& } \\
\text { employees) }\end{array}$ & $\begin{array}{l}\text { Qualitative Analysis } \\
\text { (thematic coding) }\end{array}$ & Entrepreneurial Marketing & $\begin{array}{l}\text { Personal contact networks \& their value for } \\
\text { resource leveraging in SMEs }\end{array}$ \\
\hline Jones \& Rowley & 2011 & Conceptual & N/A & $\begin{array}{l}\text { Entrepreneurial Marketing; } \\
\text { Entrepreneurial Orientation; } \\
\text { Customer Orientation }\end{array}$ & $\begin{array}{l}\text { Explores the components of entrepreneurial } \\
\text { marketing orientation }\end{array}$ \\
\hline $\begin{array}{l}\text { Karagozoglu \& } \\
\text { Lindell }\end{array}$ & 2004 & $\begin{array}{l}\text { Survey (71 owner-managers in US-based } \\
\text { SMEs) }\end{array}$ & $\begin{array}{l}\text { Quantitative Analysis } \\
\text { (component analysis) }\end{array}$ & $\begin{array}{l}\text { Descriptive or subject-matter } \\
\text { specific }\end{array}$ & $\begin{array}{l}\text { Strategic, operational, \& performance aspects of } \\
\text { SME e-commerce involvement }\end{array}$ \\
\hline $\begin{array}{l}\text { Katsikea, } \\
\text { Theodosiou, } \\
\text { Morgan \& } \\
\text { Papavassiliou }\end{array}$ & 2005 & & $\begin{array}{l}\text { Quantitative Analysis } \\
\text { (regression) }\end{array}$ & Punctuated equilibrium theory & $\begin{array}{l}\text { The influence of sales managers' characteristics } \\
\& \text { behavior \& levels of satisfaction with export } \\
\text { sales territory design on the types of international } \\
\text { customer acquisition strategies adopted by SMEs }\end{array}$ \\
\hline $\begin{array}{l}\text { Khavul, Perez- } \\
\text { Nordtvedt \& } \\
\text { Wood }\end{array}$ & 2010 & $\begin{array}{l}\text { Survey ( } 166 \text { - } 71 \text { Chinese, } 48 \text { Indian, \& } \\
47 \text { South African - senior executives in } \\
\text { internationalizing young firms) }\end{array}$ & $\begin{array}{l}\text { Quantitative Analysis (Robust } \\
\text { regression) }\end{array}$ & $\begin{array}{l}\text { International } \\
\text { entrepreneurship; } \\
\text { Organizational entrainment }\end{array}$ & $\begin{array}{l}\text { Synchronization of activity cycles between } \\
\text { internationalizing new ventures \& their key } \\
\text { customers }\end{array}$ \\
\hline $\begin{array}{l}\text { Khavul, Peterson, } \\
\text { Mullens \& } \\
\text { Rasheed }\end{array}$ & 2010 & $\begin{array}{l}\text { Survey (173 international new ventures } \\
\text { from China \& India) }\end{array}$ & $\begin{array}{l}\text { Quantitative Analysis (factor } \\
\text { analysis) }\end{array}$ & Dynamic capabilities & $\begin{array}{l}\text { Operational support of key international } \\
\text { customers }\end{array}$ \\
\hline $\begin{array}{l}\text { Kocas \& } \\
\text { Bohlman }\end{array}$ & 2008 & $\begin{array}{l}\text { Archival Data (prices set by } 14 \text { online } \\
\text { book retailers for a sample of } 2207 \text { books } \\
\text { listed on mySimon.com price comparison } \\
\text { website) }\end{array}$ & $\begin{array}{l}\text { Quantitative Analysis (theory } \\
\text { testing mathematical model) }\end{array}$ & Game theory & $\begin{array}{l}\text { Pricing strategies of online retailers selling } \\
\text { undifferentiated homogeneous goods, such as } \\
\text { books. }\end{array}$ \\
\hline $\begin{array}{l}\text { Kristiansen, } \\
\text { Kimeme, } \\
\text { Mwambo \& } \\
\text { Wahid } \\
\end{array}$ & 2005 & $\begin{array}{l}\text { Survey (392 tailoring \& woodworking } \\
\text { entrepreneurs in Tanzania) }\end{array}$ & $\begin{array}{l}\text { Quantitative Analysis } \\
\text { (bivariate correlation; Cross- } \\
\text { tabulation; one-way ANOVA) }\end{array}$ & & $\begin{array}{l}\text { Adaptability \& survival of micro \& small-scale } \\
\text { industries in developing }\end{array}$ \\
\hline Leiblein \& Reuer & 2004 & $\begin{array}{l}\text { Survey (101 US-based internationalizing } \\
\text { semiconductor ventures) }\end{array}$ & $\begin{array}{l}\text { Quantitative Analysis } \\
\text { (multivariate regression) }\end{array}$ & $\begin{array}{l}\text { Resource-based view of the } \\
\text { firm; Firm capabilities; } \\
\text { International entrepreneurship }\end{array}$ & $\begin{array}{l}\text { Internal technological skills \& intra-firm alliances } \\
\text { exhibit a positive relationship with the acquisition } \\
\text { of sales from international customers }\end{array}$ \\
\hline Lindman & 2013 & $\begin{array}{l}\text { Survey ( } 82 \text { sales people in US-based } \\
\text { retail SMEs) }\end{array}$ & $\begin{array}{l}\text { Quantitative Analysis } \\
\text { (MANOVA) }\end{array}$ & $\begin{array}{l}\text { Resource-based view of the } \\
\text { firm; Transactional exchange } \\
\text { theory }\end{array}$ & $\begin{array}{l}\text { The influence of personal selling \& sales process } \\
\text { design on customer perception of value \& loyalty }\end{array}$ \\
\hline Lofgren & 2014 & Survey (188 internationalizing SMEs) & $\begin{array}{l}\text { Quantitative Analysis (linear } \\
\text { structural relations (LISREL) } \\
\text { structural equation modeling) }\end{array}$ & $\begin{array}{l}\text { International } \\
\text { entrepreneurship; Co- } \\
\text { innovation }\end{array}$ & $\begin{array}{l}\text { SME's (i) awareness of a customer's } \\
\text { complementary knowledge \& (ii) innovation- }\end{array}$ \\
\hline
\end{tabular}




\begin{tabular}{|c|c|c|c|c|c|}
\hline & & & & & $\begin{array}{l}\text { oriented customer relationships leads to increased } \\
\text { co-innovation with key customers }\end{array}$ \\
\hline Madill \& Neilson & 2010 & $\begin{array}{l}\text { Mixed (Content analysis of the websites } \\
\text { of } 121 \text { Canadian wineries) }\end{array}$ & $\begin{array}{l}\text { Mixed Analysis (descriptive } \\
\text { statistics with narrative } \\
\text { explanation) }\end{array}$ & $\begin{array}{l}\text { Descriptive or subject-matter } \\
\text { specific }\end{array}$ & $\begin{array}{l}\text { The use of websites to build relationships \& } \\
\text { exchange information between SMEs \& } \\
\text { international customers }\end{array}$ \\
\hline Marvel \& Droege & 2010 & $\begin{array}{l}\text { Survey (145 technology venture founders } \\
\text { selected from US-based university } \\
\text { incubators) }\end{array}$ & $\begin{array}{l}\text { Quantitative Analysis } \\
\text { (logistic regression) }\end{array}$ & $\begin{array}{l}\text { Human capital; Explicit \& } \\
\text { tacit knowledge }\end{array}$ & $\begin{array}{l}\text { The role of tacit knowledge relates and } \\
\text { experience in driving early sales of high } \\
\text { technology offerings }\end{array}$ \\
\hline $\begin{array}{l}\text { McDougall \& } \\
\text { Robinson }\end{array}$ & 1990 & $\begin{array}{l}\text { Survey ( } 247 \text { CEOs in US information } \\
\text { processing ventures) }\end{array}$ & $\begin{array}{l}\text { Quantitative Analysis (factor } \\
\text { analysis; cluster analysis) }\end{array}$ & International entrepreneurship & $\begin{array}{l}\text { Developing a typology of competitive market } \\
\text { entry strategies }\end{array}$ \\
\hline $\begin{array}{l}\text { McDougall \& } \\
\text { Oviatt }\end{array}$ & 1996 & $\begin{array}{l}\text { Survey (senior managers from } 62 \text { US- } \\
\text { based internationalizing IT } \\
\text { manufacturing ventures) }\end{array}$ & $\begin{array}{l}\text { Quantitative Analysis (factor } \\
\text { analysis) }\end{array}$ & International entrepreneurship & $\begin{array}{l}\text { Internationalization strategies \& impacts on firm } \\
\text { performance }\end{array}$ \\
\hline $\begin{array}{l}\text { McKague \& } \\
\text { Tinsley }\end{array}$ & 2012 & $\begin{array}{l}\text { Case Study ( } 25 \text { interviews with rural } \\
\text { women who are the sales force within } \\
\text { Bangladeshi NGO partnership); } \\
\text { participant observation) }\end{array}$ & $\begin{array}{l}\text { Qualitative Analysis (reported } \\
\text { case) }\end{array}$ & $\begin{array}{l}\text { Descriptive or subject-matter } \\
\text { specific }\end{array}$ & $\begin{array}{l}\text { The management of direct sales agent networks } \\
\& \text { how this relates to servicing isolated, } \\
\text { disadvantaged communities in Bangladesh }\end{array}$ \\
\hline McNaughton & 2002 & $\begin{array}{l}\text { Survey (owners \& managers in } 120 \\
\text { Canadian knowledge intensive firms) }\end{array}$ & $\begin{array}{l}\text { Quantitative Analysis } \\
\text { (stepwise logistic regression) }\end{array}$ & Transaction cost economics & $\begin{array}{l}\text { Choice of export channel strategies in exporting } \\
\text { SMEs }\end{array}$ \\
\hline $\begin{array}{l}\text { Measson, } \\
\text { Campbell \& Hunt }\end{array}$ & 2015 & $\begin{array}{l}\text { Multiple Case Study ( } 6 \text { cases of New } \\
\text { Zealand-based SMEs, involving } \\
\text { interviews with CEOs \& key informants) }\end{array}$ & $\begin{array}{l}\text { Qualitative Analysis } \\
\text { (Thematic Coding) }\end{array}$ & $\begin{array}{l}\text { International } \\
\text { entrepreneurship; Network } \\
\text { theory }\end{array}$ & $\begin{array}{l}\text { The use of trade fairs to develop international } \\
\text { sales relationships. }\end{array}$ \\
\hline $\begin{array}{l}\text { Moen, Madsen \& } \\
\text { Aspelund }\end{array}$ & 2008 & Survey (635 Danish \& Norwegian SMEs) & $\begin{array}{l}\text { Quantitative Analysis } \\
\text { (structural equation } \\
\text { modelling) }\end{array}$ & $\begin{array}{l}\text { Descriptive or subject-matter } \\
\text { specific }\end{array}$ & $\begin{array}{l}\text { The use of ICT to provide information, improve } \\
\text { service quality, \& to act as a sales } \& \text { marketing } \\
\text { interface }\end{array}$ \\
\hline $\begin{array}{l}\text { Moen, Endresen } \\
\& \text { Gavlen }\end{array}$ & 2003 & $\begin{array}{l}\text { Multiple Case Study ( } 6 \text { cases of } \\
\text { Norwegian software-developing } \\
\text { companies; semi-structured interviews \& } \\
\text { archival data) }\end{array}$ & $\begin{array}{l}\text { Qualitative Analysis (reported } \\
\text { cases) }\end{array}$ & International marketing & $\begin{array}{l}\text { The use of the Internet in the international } \\
\text { marketing activities of SMEs. }\end{array}$ \\
\hline $\begin{array}{l}\text { Moen, Gavlen \& } \\
\text { Endresen }\end{array}$ & 2003 & $\begin{array}{l}\text { Multiple Case Study ( } 5 \text { Norweigan } \\
\text { software SMEs) }\end{array}$ & $\begin{array}{l}\text { Qualitative Analysis } \\
\text { (thematic coding) }\end{array}$ & $\begin{array}{l}\text { Network theory; International } \\
\text { entrepreneurship }\end{array}$ & $\begin{array}{l}\text { The use of network agents to access international } \\
\text { sales markets }\end{array}$ \\
\hline $\begin{array}{l}\text { Morgan-Thomas } \\
\text { \& Jones }\end{array}$ & 2010 & $\begin{array}{l}\text { Survey (200 UK-based newly } \\
\text { internationalizing firms) }\end{array}$ & $\begin{array}{l}\text { Quantitative Analysis } \\
\text { (ANOVA test) }\end{array}$ & $\begin{array}{l}\text { Resource-based view of the } \\
\text { firm; International } \\
\text { entrepreneurship }\end{array}$ & $\begin{array}{l}\text { Post-entry international sales development speed, } \\
\text { diversification strategies, \& links to firm } \\
\text { knowledge intensity \& ICT usage. Rapid } \\
\text { internationalizers have greater knowledge } \\
\text { intensity \& more diversified strategies. }\end{array}$ \\
\hline $\begin{array}{l}\text { Morris, Avila \& } \\
\text { Teeple }\end{array}$ & 1990 & $\begin{array}{l}\text { Survey (114 sales managers from a cross } \\
\text { section of managers Midwestern } \\
\text { industrial firms in the US. }\end{array}$ & $\begin{array}{l}\text { Quantitative Analysis } \\
\text { (multiple regression) }\end{array}$ & $\begin{array}{l}\text { Descriptive or subject-matter } \\
\text { specific }\end{array}$ & $\begin{array}{l}\text { The role of entrepreneurial attitudes \& behaviours } \\
\text { in sales management }\end{array}$ \\
\hline $\begin{array}{l}\text { Ngugi, Johnsen \& } \\
\text { Erdélyi }\end{array}$ & 2010 & $\begin{array}{l}\text { Multiple Case Study ( } 3 \text { cases of UK } \\
\text { organic food SMEs working in } \\
\text { relationships with large retail }\end{array}$ & $\begin{array}{l}\text { Qualitative Analysis } \\
\text { (thematic coding) }\end{array}$ & $\begin{array}{l}\text { Relational capabilities; } \\
\text { network theory; value co- } \\
\text { creation }\end{array}$ & $\begin{array}{l}\text { The relational capabilities employed by SME } \\
\text { suppliers can enable them to inform \& support } \\
\text { innovation \& the implementation of initiatives to }\end{array}$ \\
\hline
\end{tabular}




\begin{tabular}{|c|c|c|c|c|c|}
\hline & & $\begin{array}{l}\text { supermarket customers, involving semi- } \\
\text { structured interviews with managers, } \\
\text { employees; \& observation) }\end{array}$ & & & $\begin{array}{l}\text { create value in the eyes of their current \& } \\
\text { potential customers. }\end{array}$ \\
\hline $\begin{array}{l}\text { Nguyen \& } \\
\text { Waring }\end{array}$ & 2011 & $\begin{array}{l}\text { Survey (126 senior managers in US- } \\
\text { based technology-based SMEs) }\end{array}$ & $\begin{array}{l}\text { Quantitative Analysis } \\
\text { (multiple regression) }\end{array}$ & $\begin{array}{l}\text { Customer relationship } \\
\text { management }\end{array}$ & $\begin{array}{l}\text { Managerial decisions to adopt CRM systems in } \\
\text { technology SMEs }\end{array}$ \\
\hline $\begin{array}{l}\text { Nguyen, Newby } \\
\& \text { Macaulay }\end{array}$ & 2015 & $\begin{array}{l}\text { Survey (105 owner-managers in US- } \\
\text { based SMEs) }\end{array}$ & $\begin{array}{l}\text { Quantitative Analysis } \\
\text { (structural equation } \\
\text { modelling) }\end{array}$ & Customer orientation & $\begin{array}{l}\text { IT adoption in SMEs is primarily driven by } \\
\text { customers }\end{array}$ \\
\hline $\begin{array}{l}\text { O'Dwyer \& } \\
\text { Ledwith }\end{array}$ & 2008 & Survey (26 Irish SMEs) & $\begin{array}{l}\text { Quantitative Analysis (t-test; } \\
\text { Spearman correlation } \\
\text { analysis) }\end{array}$ & Customer orientation & $\begin{array}{l}\text { Finds a lack of significant relationships between } \\
\text { performance \& customer orientation }\end{array}$ \\
\hline $\begin{array}{l}\text { Peltier, } \\
\text { Schibrowsky \& } \\
\text { Zhao }\end{array}$ & 2009 & Survey (386 US-based small retailers) & $\begin{array}{l}\text { Quantitative Analysis } \\
\text { (logistic regression) }\end{array}$ & $\begin{array}{l}\text { Market orientation; } \\
\text { entrepreneurial orientation }\end{array}$ & $\begin{array}{l}\text { Owner-manager entrepreneurial \& marketing } \\
\text { orientations \& impacts on the adoption of CRM } \\
\text { systems }\end{array}$ \\
\hline $\begin{array}{l}\text { Perez, Whitelock } \\
\& \text { Florin }\end{array}$ & 2011 & $\begin{array}{l}\text { Multiple Case Study ( } 3 \text { 'learning } \\
\text { alliances' between SMEs \& B2B } \\
\text { customers, involving interviews with } \\
\text { informants from firm \& customer side, } \\
\text { plus archival data) }\end{array}$ & $\begin{array}{l}\text { Qualitative Analysis } \\
\text { (thematic coding) }\end{array}$ & Value co-creation & $\begin{array}{l}\text { The exchange of existing knowledge \& the joint } \\
\text { development of new knowledge during } \\
\text { interactions with B2B customers }\end{array}$ \\
\hline Prashantham, S & 2011 & Survey (102 Indian software SMEs) & $\begin{array}{l}\text { Quantitative Analysis } \\
\text { (logistic regression) }\end{array}$ & $\begin{array}{l}\text { Social capital; International } \\
\text { entrepreneurship }\end{array}$ & $\begin{array}{l}\text { Bonding \& cross-border coethnic ties as means to } \\
\text { support SME internationalization }\end{array}$ \\
\hline $\begin{array}{l}\text { Prause, Mendez, } \\
\& \text { Garcia-Agreda }\end{array}$ & 2013 & $\begin{array}{l}\text { Mixed (10 interviews \& survey with } 434 \\
\text { customers of travel agencies) }\end{array}$ & $\begin{array}{l}\text { Quantitative Analysis } \\
\text { (structural equation } \\
\text { modelling) }\end{array}$ & $\begin{array}{l}\text { Customer relationship } \\
\text { management; trust; attitudinal } \\
\text { loyalty }\end{array}$ & $\begin{array}{l}\text { Attitudinal loyalty of customers in service } \\
\text { delivery relationships }\end{array}$ \\
\hline $\begin{array}{l}\text { Preece, Miles \& } \\
\text { Baetz }\end{array}$ & 1999 & $\begin{array}{l}\text { Survey ( } 75 \text { Canadian early stage high- } \\
\text { tech ventures) }\end{array}$ & $\begin{array}{l}\text { Quantitative Analysis } \\
\text { (multiple regression) }\end{array}$ & $\begin{array}{l}\text { Resource-based view of the } \\
\text { firm; International } \\
\text { entrepreneurship; } \\
\text { internationalization } \\
\text { orientation }\end{array}$ & $\begin{array}{l}\text { New international customer acquisition \& } \\
\text { geographical diversity, \& links to strategic } \\
\text { alliances \& internationalization orientation. }\end{array}$ \\
\hline $\begin{array}{l}\text { Raymond \& St- } \\
\text { Pierre }\end{array}$ & 2004 & $\begin{array}{l}\text { Survey (179 Canadian manufacturing } \\
\text { SMEs) }\end{array}$ & $\begin{array}{l}\text { Quantitative Analysis (partial } \\
\text { least squares regression) }\end{array}$ & Customer dependency & $\begin{array}{l}\text { Impacts of customer dependency in } \\
\text { manufacturing SMEs }\end{array}$ \\
\hline $\begin{array}{l}\text { Rehme \& } \\
\text { Svensson }\end{array}$ & 2011 & $\begin{array}{l}\text { Comparative case study (Real-time } \\
\text { observations \& operational performance } \\
\text { data, archival data in } 2 \text { Swedish } \\
\text { technology-based B2B startups) }\end{array}$ & $\begin{array}{l}\text { Qualitative Analysis } \\
\text { (thematic coding) }\end{array}$ & Relationship marketing & $\begin{array}{l}\text { Networking with external stakeholders, } \\
\text { establishing credibility, \& links to the } \\
\text { achievement of first sales in startup firms }\end{array}$ \\
\hline Reuber \& Fischer & 2002 & $\begin{array}{l}\text { Survey (187 CEOs or TMT members in } \\
\text { Canadian SMEs. } 90 \text { in the software } \\
\text { products industry \& } 97 \text { in the food } \\
\text { processing industry) }\end{array}$ & $\begin{array}{l}\text { Quantitative Analysis } \\
\text { (logistic regression) }\end{array}$ & $\begin{array}{l}\text { International } \\
\text { entrepreneurship; } \\
\text { Entrepreneurial team } \\
\text { dynamics }\end{array}$ & $\begin{array}{l}\text { Behavioral integration of EMT \& links to new } \\
\text { international customer acquisition }\end{array}$ \\
\hline Reuber \& Fischer & 2009 & $\begin{array}{l}\text { Archival Data (Online sellers from over } \\
25 \text { countries on download.com) }\end{array}$ & $\begin{array}{l}\text { Quantitative Analysis (OLS } \\
\text { regression) }\end{array}$ & Signaling theory & $\begin{array}{l}\text { How a firm controls it's 'reputation signals' \& } \\
\text { how this impacts reputational performance }\end{array}$ \\
\hline
\end{tabular}




\begin{tabular}{|c|c|c|c|c|c|}
\hline $\begin{array}{l}\text { Roman, Ruiz \& } \\
\text { Munuera }\end{array}$ & 2002 & $\begin{array}{l}\text { Survey (115 Spanish SMEs that had } \\
\text { implemented sales training) }\end{array}$ & $\begin{array}{l}\text { Quantitative analysis } \\
\text { (regression \& MANOVA) }\end{array}$ & $\begin{array}{l}\text { Descriptive or subject-matter } \\
\text { specific }\end{array}$ & $\begin{array}{l}\text { The effects of training on SME sales force } \\
\text { activity }\end{array}$ \\
\hline $\begin{array}{l}\text { Ruiz-Arroyo, del } \\
\text { Mar Fuentes- } \\
\text { Fuentes, Bojica \& } \\
\text { Rodríguez-Ariza }\end{array}$ & 2012 & $\begin{array}{l}\text { Survey (111 Spanish women } \\
\text { entrepreneurs) }\end{array}$ & $\begin{array}{l}\text { Quantitative Analysis } \\
\text { (ANOVA test) }\end{array}$ & $\begin{array}{l}\text { Descriptive or subject-matter } \\
\text { specific }\end{array}$ & $\begin{array}{l}\text { The role of knowledge acquisition from } \\
\text { customers \& impacts on innovativeness }\end{array}$ \\
\hline $\begin{array}{l}\text { Ruokonen, } \\
\text { Nummela, } \\
\text { Puumalainen \& } \\
\text { Saarenketo }\end{array}$ & 2008 & $\begin{array}{l}\text { Multiple Case Study ( } 2 \text { Finnish software } \\
\text { SMEs involving manager interviews \& } \\
\text { archival data) }\end{array}$ & $\begin{array}{l}\text { Mixed Analysis (descriptive } \\
\text { statistics with narrative } \\
\text { explanation) }\end{array}$ & Market orientation & $\begin{array}{l}\text { Market orientation in the internationalization of } \\
\text { small software firms. }\end{array}$ \\
\hline Sandberg & 2013 & $\begin{array}{l}\text { Survey (197 Swedish internationalizing } \\
\text { SMEs) }\end{array}$ & $\begin{array}{l}\text { Quantitative Analysis } \\
\text { (ANOVA test) }\end{array}$ & International entrepreneurship & $\begin{array}{l}\text { The 'nodes' used by SMEs to establish entry into } \\
\text { a foreign market network }\end{array}$ \\
\hline Shipley \& Jobber & 1994 & $\begin{array}{l}\text { Survey (95 Sales Directors in Irish } \\
\text { manufacturing SMEs) }\end{array}$ & $\begin{array}{l}\text { Qualitative Analysis (reported } \\
\text { cases) }\end{array}$ & $\begin{array}{l}\text { Descriptive or subject-matter } \\
\text { specific }\end{array}$ & $\begin{array}{l}\text { Salary \& payment structures in SME Sales \& } \\
\text { Distribution departments }\end{array}$ \\
\hline $\begin{array}{l}\text { Simpson \& } \\
\text { Dochery }\end{array}$ & 2004 & Qualitative interviews & Reported interviews & $\begin{array}{l}\text { Descriptive or subject-matter } \\
\text { specific }\end{array}$ & E-commerce adoption in SMEs \\
\hline $\begin{array}{l}\text { Sinkovics, } \\
\text { Sinkovics \& Jean }\end{array}$ & 2012 & Survey (115 UK international SMEs) & $\begin{array}{l}\text { Quantitative Analysis (partial } \\
\text { least squares regression) }\end{array}$ & $\begin{array}{l}\text { Descriptive or subject-matter } \\
\text { specific }\end{array}$ & $\begin{array}{l}\text { The use of the Internet in international sales } \\
\text { management }\end{array}$ \\
\hline Siu & 2005 & $\begin{array}{l}\text { Content analysis of } 391 \text { news stories } \\
\text { about Chines owner managers }\end{array}$ & Narrative analysis & Institutional theory & $\begin{array}{l}\text { Institutional differences in SME customer } \\
\text { relationship practices across China, Hong Kong, } \\
\text { \& Taiwan }\end{array}$ \\
\hline $\begin{array}{l}\text { Song, Wang \& } \\
\text { Parry }\end{array}$ & 2010 & $\begin{array}{l}\text { Survey ( } 259 \text { Venture backed firms in the } \\
\text { USA). }\end{array}$ & $\begin{array}{l}\text { Quantitative Analysis } \\
\text { (descriptive statistics \& } \\
\text { multiple regression) }\end{array}$ & $\begin{array}{l}\text { Market orientation view of } \\
\text { the firm }\end{array}$ & $\begin{array}{l}\text { Formal processes for retaining market } \\
\text { information from customer interactions improve } \\
\text { firm performance }\end{array}$ \\
\hline Spilleke \& Brettel & 2014 & $\begin{array}{l}\text { Survey ( } 268 \text { executives in German } \\
\text { SMEs) }\end{array}$ & $\begin{array}{l}\text { Quantitative Analysis } \\
\text { (structural equation modelling } \\
\text { - two step) }\end{array}$ & Entrepreneurial Orientation & $\begin{array}{l}\text { EO of SME Sales departments. Emphasizes the } \\
\text { role of management practices, reward systems \& } \\
\text { control signals and links these to sales } \\
\text { performance. }\end{array}$ \\
\hline $\begin{array}{l}\text { Stanworth, } \\
\text { Brodie, Wotruba } \\
\text { \& Purdy }\end{array}$ & 2004 & $\begin{array}{l}\text { Survey ( } 673 \text { sales agents from UK-based } \\
\text { 'direct selling' firms; followed by } \\
\text { interviews with a random sample of } 82 \\
\text { agents) }\end{array}$ & $\begin{array}{l}\text { Qualitative Analysis } \\
\text { (thematic coding) }\end{array}$ & $\begin{array}{l}\text { Descriptive or subject-matter } \\
\text { specific }\end{array}$ & $\begin{array}{l}\text { The use of 'independent contractors' to undertake } \\
\text { direct selling as opposed to building up sales } \\
\text { department }\end{array}$ \\
\hline Tseng \& Johnsen & 2011 & $\begin{array}{l}\text { Multiple Case Study ( } 16 \text { owners or } \\
\text { managers interviewed across the } 10 \mathrm{UK} \\
\text { manufacturing SMEs) }\end{array}$ & $\begin{array}{l}\text { Qualitative Analysis } \\
\text { (thematic coding) }\end{array}$ & $\begin{array}{l}\text { Descriptive or subject-matter } \\
\text { specific }\end{array}$ & $\begin{array}{l}\text { The influence of the internet on international } \\
\text { customer relationship interactions }\end{array}$ \\
\hline Varadarajan & 1985 & $\begin{array}{l}\text { Survey ( } 31 \text { executive in US-based } \\
\text { independent retail firms) }\end{array}$ & $\begin{array}{l}\text { Mixed Analysis (descriptive } \\
\text { statistics with narrative } \\
\text { explanation) }\end{array}$ & $\begin{array}{l}\text { Descriptive or subject-matter } \\
\text { specific }\end{array}$ & $\begin{array}{l}\text { The planning of sales promotion strategies in } \\
\text { retail SMEs }\end{array}$ \\
\hline Verdin & 1986 & $\begin{array}{l}\text { Single Case Study (US-based } \\
\text { independent retail chain) }\end{array}$ & $\begin{array}{l}\text { Quantitative Analysis } \\
\text { (descriptive statistics \& } \\
\text { multiple regression) }\end{array}$ & $\begin{array}{l}\text { Descriptive or subject-matter } \\
\text { specific }\end{array}$ & $\begin{array}{l}\text { Feedback, goal-setting \& links to increasing } \\
\text { productivity in the sales departments of small, } \\
\text { family-owned businesses. }\end{array}$ \\
\hline
\end{tabular}




\begin{tabular}{|c|c|c|c|c|c|}
\hline $\begin{array}{l}\text { Viswanathan, } \\
\text { Sridharan, Richie, } \\
\text { Venugopal \& } \\
\text { Jung }\end{array}$ & 2012 & $\begin{array}{l}\text { Qualitative interviews with } 30 \text { consumers } \\
\& 16 \text { entrepreneurs in survivalist } \\
\text { microenterprises in the South-Indian } \\
\text { subsistence marketplace }\end{array}$ & $\begin{array}{l}\text { Qualitative Analysis } \\
\text { (grounded open coding) }\end{array}$ & $\begin{array}{l}\text { Social capital; Social } \\
\text { exchange }\end{array}$ & $\begin{array}{l}\text { Buyer-seller responsiveness - gratitude, respect, } \\
\& \text { friendship underpinning the mutual social } \\
\text { obligations that are part of sales interactions }\end{array}$ \\
\hline $\begin{array}{l}\text { Westhead, Wright } \\
\text { \& Ucbasaran }\end{array}$ & 2001 & $\begin{array}{l}\text { Survey (621 UK-based construction \& } \\
\text { manufacturing SMEs; follow up } \\
\text { interviews conducted) }\end{array}$ & $\begin{array}{l}\text { Quantitative Analysis } \\
\text { (logistic regression \& forced- } \\
\text { entry multiple regression } \\
\text { analysis) }\end{array}$ & $\begin{array}{l}\text { Resource-based view of the } \\
\text { firm; Human capital; } \\
\text { International entrepreneurship }\end{array}$ & $\begin{array}{l}\text { EMT human capital \& heterogeneity \& links to } \\
\text { new international customer acquisition. }\end{array}$ \\
\hline $\begin{array}{l}\text { Wiesel, Pauwels } \\
\& \text { Arts }\end{array}$ & 2011 & Single case study (web analytics) & $\begin{array}{l}\text { Experimental Quantitative } \\
\text { Analysis (Granger causality } \\
\text { tests; Unit root \& } \\
\text { cointegration tests) }\end{array}$ & $\begin{array}{l}\text { Descriptive or subject-matter } \\
\text { specific }\end{array}$ & $\begin{array}{l}\text { SME marketing communication activities \& } \\
\text { customer funneling }\end{array}$ \\
\hline $\begin{array}{l}\text { Wood, Khavul, } \\
\text { Perez-Nordtvelt, } \\
\text { Prakhya, } \\
\text { Dabrowski \& } \\
\text { Zheng }\end{array}$ & 2011 & $\begin{array}{l}\text { Structured interview (257 SMEs: } 83 \\
\text { Chinese, } 79 \text { Indian, } 55 \text { South African, \& } \\
40 \text { Mexican new ventures) }\end{array}$ & $\begin{array}{l}\text { Quantitative Analysis } \\
\text { (multinominal logit; } \\
\text { hierarchical regression) }\end{array}$ & $\begin{array}{l}\text { Resource-based view of the } \\
\text { firm; International } \\
\text { entrepreneurship }\end{array}$ & $\begin{array}{l}\text { Impact of strategic commitment \& intentionality } \\
\text { on achieving international sales }\end{array}$ \\
\hline Yang \& Kuo & 1996 & $\begin{array}{l}\text { Single Case Study (performance data } \\
\text { from the sales department of a Taiwanese } \\
\text { SME) }\end{array}$ & Mathematical modelling & Agency theory & $\begin{array}{l}\text { The impact of compensation/reward plans on } \\
\text { manager/out-of-office sales staff relationship } \\
\text { governance }\end{array}$ \\
\hline $\begin{array}{l}\text { Yli-Renko, } \\
\text { Sapienza \& Hay }\end{array}$ & 2001 & $\begin{array}{l}\text { Survey (195 UK-based new technology- } \\
\text { based firms) }\end{array}$ & Quantitative Analysis & $\begin{array}{l}\text { Resource dependence } \\
\text { perspective }\end{array}$ & $\begin{array}{l}\text { The management of relationships with powerful } \\
\text { customers }\end{array}$ \\
\hline $\begin{array}{l}\text { Yli-Renko \& } \\
\text { Janakiraman }\end{array}$ & 2008 & $\begin{array}{l}\text { Survey ( } 180 \text { Managing Directors in UK } \\
\text { technology ventures) }\end{array}$ & $\begin{array}{l}\text { Quantitative Analysis (Zero- } \\
\text { Inflated Poisson Model; Tobit } \\
\text { II Model) }\end{array}$ & $\begin{array}{l}\text { Resource dependence } \\
\text { perspective; Relational } \\
\text { perspective }\end{array}$ & $\begin{array}{l}\text { The influence of customer portfolio on new } \\
\text { product development }\end{array}$ \\
\hline $\begin{array}{l}\text { Yli-Renko, Autio } \\
\& \text { Sapienza }\end{array}$ & 2001 & $\begin{array}{l}\text { Survey (180 CEOs in UK technology } \\
\text { ventures) }\end{array}$ & $\begin{array}{l}\text { Quantitative Analysis } \\
\text { (structural equation } \\
\text { modelling) }\end{array}$ & $\begin{array}{l}\text { Organizational learning; } \\
\text { Social capital; Relational } \\
\text { Perspective; Resource based } \\
\text { view }\end{array}$ & $\begin{array}{l}\text { Knowledge exchange between firms \& customers } \\
\text { leading to wealth creation. }\end{array}$ \\
\hline $\begin{array}{l}\text { Yu, Gilbert \& } \\
\text { Oviatt }\end{array}$ & 2011 & $\begin{array}{l}\text { Secondary Data Source (longitudinal } \\
\text { dataset of } 118 \text { US-based biotechnology } \\
\text { ventures that achieved IPO status) }\end{array}$ & $\begin{array}{l}\text { Quantitative Analysis (Cox } \\
\text { proportional hazard model) }\end{array}$ & $\begin{array}{l}\text { Network theory; International } \\
\text { entrepreneurship }\end{array}$ & $\begin{array}{l}\text { Knowledge derived from ventures' technology \& } \\
\text { marketing alliances increases the likelihood that } \\
\text { new ventures will acquire international } \\
\text { customers. }\end{array}$ \\
\hline $\begin{array}{l}\text { Zahra, Matherne } \\
\& \text { Carleton }\end{array}$ & 2003 & $\begin{array}{l}\text { Survey ( } 220 \text { executives in } 159 \text { US-based } \\
\text { software ventures) }\end{array}$ & $\begin{array}{l}\text { Quantitative Analysis } \\
\text { (logistical regression; } \\
\text { multiple regression) }\end{array}$ & $\begin{array}{l}\text { Resource-based view of the } \\
\text { firm; International } \\
\text { entrepreneurship }\end{array}$ & $\begin{array}{l}\text { Technological networks \& technological } \\
\text { reputations \& links to new international customer } \\
\text { acquisition }\end{array}$ \\
\hline Zhao \& Aram & 1995 & $\begin{array}{l}\text { Multiple Case Study ( } 6 \text { cases of Chinese- } \\
\text { based technology firms, involving } 60 \\
\text { interviews with 'network associates') }\end{array}$ & $\begin{array}{l}\text { Qualitative Analysis } \\
\text { (thematic coding) }\end{array}$ & Network theory & $\begin{array}{l}\text { Networking practices \& associations with } \\
\text { customer relationships }\end{array}$ \\
\hline
\end{tabular}




\section{Bibliography}

Ahrne, G., P. Aspers and N. Brunsson. 2015. The organization of markets. Organization Studies 36(1): 7-27.

Ali, H. 1995. Gateways to market entry. Journal of Entrepreneurship 4(1): 49-69.

Altinay, L., M. N. K. Saunders and C. L. Wang. 2014. The Influence of Culture on Trust Judgments in Customer Relationship Development by Ethnic Minority Small Businesses. Journal of Small Business Management 52(1): 59-78.

Alvarez, S. and J. Barney. 2007. Discovery and creation: Alternative theories of entrepreneurial action. Strategic Entrepreneurship Journal 1: 11-26.

Alvarez, S. A., S. L. Young and J. L. Woolley. 2015. Opportunities and institutions: A cocreation story of the king crab industry. Journal of Business Venturing 30(1): 95-112.

Amit, R. and P. Schoemaker. 1993. Strategic assets and organizational rent. Strategic Management Journal 14(1): 33-46.

Anderson, E. and V. Onyemah. 2006. How right should the customer be? Harvard Business Review 84(7-8): 58-67, 185.

Arenius, P., V. Sasi and M. Gabrielsson. 2005. Rapid internationalisation enabled by the Internet: The case of a knowledge intensive company. Journal of International Entrepreneurship 3(4): 279-90.

Avlonitis, G. J. and N. G. Panagopoulos. 2010. Selling and sales management: An introduction to the special section and recommendations on advancing the sales research agenda. Industrial Marketing Management 39(7): 1045-8.

Barney, J. 1991. Firm resources and sustained competitive advantage. Journal of Management 17(1): 99-120.

Baron, R. and M. Ensley. 2006. Opportunity recognition as the detection of meaningful patterns: Evidence from comparisons of novice and experienced entrepreneurs. Management Science 52: 1331-134.

Bates, T. 2002. Restricted access to markets characterizes women-owned businesses. Journal of Business Venturing 17(4): 313-24.

Baumol, W. J. 1968. Entrepreneurship in economic theory. The American economic review: 64-71.

Belk, R., J. Sherry and M. Wallendorf. 1988. A Naturalistic Inquiry into Buyer and Seller Behaviour at a Swap Meet. Journal of Consumer Research 14: 449-70.

Bharadwaj, P. N. and R. G. Soni. 2007. E-Commerce Usage and Perception of E-Commerce Issues among Small Firms: Results and Implications from an Empirical Study. Journal of Small Business Management 45(4): 501-21. 
Binz, C., J. F. Hair Jr, T. M. Pieper and A. Baldauf. 2013. Exploring the effect of distinct family firm reputation on consumers' preferences. Journal of Family Business Strategy 4(1): 3-11.

Bjørnåli, E. S. and A. Aspelund. 2012. The role of the entrepreneurial team and the board of directors in the internationalization of academic spin-offs. Journal of International Entrepreneurship 10(4): 350-77.

Block, Z. and I. C. MacMillan. 1985. Milestones for successful venture planning. Harvard Business Review 63(5): 184-\&.

Boag, D. A. 1987. Marketing control and performance in early-growth companies. Journal of Business Venturing 2(4): 365-79.

Bonney, F. L. and B. C. Williams. 2009. From products to solutions: the role of salesperson opportunity recognition. European Journal of Marketing 43(7/8): 1032-52.

Bonoma, T. V. 2006. Major sales: who really does the buying? Harvard Business Review 84(7/8): 172.

Brooks, A. W., L. Huang, S. W. Kearney and F. E. Murray. 2014. Investors prefer entrepreneurial ventures pitched by attractive men. Proceedings of the National Academy of Sciences 111(12): 4427-31.

Brouthers, L. N., G; Hadjimarcou, Brouthers, K. 2009. Key Factors for Successful Export Performance for Small Firms. Journal of International Marketing 17(3): 21-38.

Burgel, O. M., G. 2000. The International Market Entry Choices of Start-Up Companies in High-Technology Industries. Journal of International Marketing 8(2): 33-62.

Busenitz, L. W., L. A. Plummer, A. C. Klotz, A. Shahzad and K. Rhoads. 2014. Entrepreneurship research (1985-2009) and the emergence of opportunities. Entrepreneurship Theory and Practice 38(5): 981-1000.

Butler, R. S. 1917. Marketing methods, Alexander Hamilton Institute.

Carlsson, B., P. Braunerhjelm, M. McKelvey, C. Olofsson, L. Persson and H. Ylinenpää. 2013. The evolving domain of entrepreneurship research. Small Business Economics 41(4): 913-30.

Cespedes, F. and D. Weinfurter. 2016. More universities need to teach sales. April 26, https://hbr.org/2016/04/more-universities-need-to-teach-sales.

Chan, K. W., C. K. Yim and S. S. K. Lam. 2010. Is Customer Participation in Value Creation a Double-Edged Sword? Evidence from Professional Financial Services Across Cultures. Journal of Marketing 74(3): 48-64.

Choi, Y., M. Lévesque and D. Shepherd. 2008. When should entrepreneurs expedite or delay opportunity exploitation? Journal Business Venturing 23(3): 333-55. 
Chowdhury, S. 2011. The moderating effects of customer driven complexity on the structure and growth relationship in young firms. Journal of Business Venturing 26(3): 306-20.

Clarke, J. 2011. Revitalizing entrepreneurship: how visual symbols are used in entrepreneurial performances. Journal of Management Studies 48(6): 1365-91.

Cogliser, C. C. and K. H. Brigham. 2004. The intersection of leadership and entrepreneurship: Mutual lessons to be learned. The Leadership Quarterly 15(6): 771-99.

Cooper, M. J., N. Upton and S. Seaman. 2005. Customer Relationship Management: A Comparative Analysis of Family and Nonfamily Business Practices. Journal of Small Business Management 43(3): 242-56.

Corner, P. and M. Ho. 2010. How opportunities develop in social entrepreneurship. Entrepreneurship Theory and Practice 34(4): 635-59.

Cossío Silva, F. J., M. A. Revilla Camacho and M. Vega Vázquez. 2013. Heterogeneity of customers of personal image services: a segmentation based on value co-creation. International Entrepreneurship and Management Journal 9(4): 619-30.

Coviello, N. E., R. J. Brodie and H. J. Munro. 2000. An investigation of marketing practice by firm size. Journal of Business Venturing 15(5-6): 523-45.

Coviello, N. E. and R. M. Joseph. 2012. Creating Major Innovations with Customers: Insights from Small and Young Technology Firms. Journal of Marketing 76(6): 87-104.

Daniel, E., H. Wilson and A. Myers. 2002. Adoption of E-Commerce by SMEs in the UK: Towards a Stage Model. International Small Business Journal 20(3): 253-70.

Darr, A. 2011. Sales work and the situated constitution of legitimate economic exchange. Work, Employment and Society 25(3): 506-21.

Darr, A. and T. Pinch. 2013. Performing sales: Material scripts and the social organization of obligation. Organization Studies 34(11): 1601-21.

Darr, A. and I. Talmud. 2003. The structure of knowledge and seller-buyer networks in markets for emergent technologies. Organization Studies 24(3): 443-61.

Davidsson, P. 2015. Entrepreneurial opportunities and the entrepreneurship nexus: A reconceptualization. Journal of Business Venturing 30(5): 674-95.

De Clercq, D., D. Dimov and N. Thongpapanl. 2010. The moderating impact of internal social exchange processes on the entrepreneurial orientation-performance relationship. Journal of Business Venturing 25(1): 87-103.

De Clercq, D. and D. Rangarajan. 2008. The role of perceived relational support in entrepreneur-customer dyads. Entrepreneurship Theory and Practice 32(4): 659-83.

de Jong, J. P. 2013. The Decision to Exploit Opportunities for Innovation: A Study of HighTech Small-Business Owners. Entrepreneurship Theory and Practice 37(2): 281-301. 
Deeter-Schmelz, D. R. and K. N. Kennedy. 2011. A global perspective on the current state of sales education in the college curriculum. Journal of Personal Selling \& Sales Management 31(1): 55-75.

Dellarocas, C. 2003. The digitization of word of mouth: Promise and challenges of online feedback mechanisms. Management science 49(10): 1407-24.

Denyer, D. and D. Tranfield (2008). Producing a systematic review. The Sage Handbook of Organizational Research Methods. D. Buchanan. London, Sage: 671-89.

Dessì, C. and M. Floris. 2010. When management and customers see eye-to-eye: the agreement factor and performance. Journal of Small Business and Enterprise Development 17(1): 102-22.

Dessi, C., W. Ng, M. Floris and S. Cabras. 2014. How small family-owned businesses may compete with retail superstores: Tacit knowledge and perceptive concordance among ownermanagers and customers. Journal of Small Business and Enterprise Development 21(4): 66889.

Dholakia, R. R. and N. Kshetri. 2004. Factors impacting the adoption of the Internet among SMEs. Small Business Economics 23(4): 311-22.

Dimov, D. 2011. Grappling with the unbearable elusiveness of entrepreneurial opportunities. Entrepreneurship Theory and Practice 35(1): 57-81.

Dubinsky, A. J. 1981. A factor analytic study of the personal selling process. Journal of Personal Selling \& Sales Management 1(1): 26-33.

Dyer, L. M. and C. A. Ross. 2000. Ethnic Enterprises and their Clientele. Journal of Small Business Management 38(2): 48-66.

Dyer, W. G. 2001. Network Marketing: An Effective Business Model for Family-Owned Businesses? Family Business Review 14(2): 97-104.

Eckhardt, J. T. and S. A. Shane. 2003. Opportunities and entrepreneurship. Journal of management 29(3): 333-49.

Eggers, F., F. Eggers and S. Kraus. 2016. Entrepreneurial branding: measuring consumer preferences through choice-based conjoint analysis. International Entrepreneurship and Management Journal 12(2): 427-44.

Evans, F. B. 1963. Selling as a Dyadic Relationship - A New Approach. American Behavioral Scientist 6(9): 76-9.

Evans, K. R., R. G. McFarland, B. Dietz and F. Jaramillo. 2012. Advancing Sales Performance Research: A Focus on Five UnderResearched Topic Areas. Journal of Personal Selling \& Sales Management 32(1): 89-105.

Fernandes, T. and P. Remelhe. 2016. How to engage customers in co-creation: customers' motivations for collaborative innovation. Journal of Strategic Marketing 24(3-4): 311-26. 
Fillis, I., U. Johansson and B. Wagner. 2004. A qualitative investigation of smaller firm ebusiness development. Journal of Small Business and Enterprise Development 11(3): 349-61.

Fischer, E. and A. R. Reuber. 2004. Contextual antecedents and consequences of relationships between young firms and distinct types of dominant exchange partners. Journal of Business Venturing 19(5): 681-706.

Fischer, E. and A. R. Reuber. 2011. Social interaction via new social media:(How) can interactions on Twitter affect effectual thinking and behavior? Journal of business venturing 26(1): 1-18.

Fischer, E. and A. R. Reuber. 2014. Online entrepreneurial communication: Mitigating uncertainty and increasing differentiation via Twitter. Journal of Business Venturing 29(4): 565-83.

Friestad, M. and P. Wright. 1994. The Persuasion Knowledge Model: How People Cope with Persuasion Attempts. Journal of Consumer Research 21: 1-31.

Fuller, T. and J. Lewis. 2002. 'Relationships Mean Everything'; A Typology of SmallBusiness Relationship Strategies in a Reflexive Context. British Journal of Management 13(4): 317-36.

Gao, H., M. Ren, J. Zhang and R. Sun. 2016. Network gatekeeping in SME exporters' market entry in China. International Marketing Review 33(2): 276-97.

Garfinkel, H. 1967. Studies in ethnomethodology, Prentice-Hall.

Gatewood, E. J., K. G. Shaver and W. B. Gartner. 1995. A longitudinal study of cognitive factors influencing start-up behaviors and success at venture creation. Journal of Business Venturing 10(5): 371-91.

Geiger, S. and P. Guenzi. 2009. The sales function in the twenty-first century: where are we and where do we go from here? European Journal of Marketing 43(7/8): 873-89.

Geiger, S. and S. Kelly. 2014. Sales-as-practice: an introduction and methodological outline. Journal of Personal Selling \& Sales Management 34(3): 223-31.

George, G. and A. J. Bock. 2011. The business model in practice and its implications for entrepreneurship research. Entrepreneurship theory and practice 35(1): 83-111.

Gioia, D. A., K. G. Corley and A. L. Hamilton. 2013. Seeking Qualitative Rigor in Inductive Research: Notes on the Gioia Methodology. Organizational Research Methods 16(1): 15-31.

Godley, A. C. 2013. Entrepreneurial Opportunities, Implicit Contracts, and Market Making for Complex Consumer Goods. Strategic Entrepreneurship Journal 7(4): 273-87.

Goffman, E. 1983. The interaction order: American Sociological Association, 1982 presidential address. American sociological review: 1-17. 
Graebner, M. E. and K. M. Eisenhardt. 2004. The seller's side of the story: Acquisition as courtship and governance as syndicate in entrepreneurial firms. Administrative Science Quarterly 49(3): 366-403.

Gruber, M., F. Heinemann, M. Brettel and S. Hungeling. 2010. Configurations of resources and capabilities and their performance implications: an exploratory study on technology ventures. Strategic Management Journal 31(12): 1337-56.

Gurau, C. G. and F. E. Duquesnois. 2011. The Website as an Integrated Marketing Tool: An Exploratory Study of French Wine Producers. Journal of Small Business and Entrepreneurship 24(1): 17-28,151.

Hakala, H. and M. Kohtamäki. 2010. The interplay between orientations: Entrepreneurial, technology, and customer orientations in software companies. Journal of Enterprising Culture 18(3): 265-90.

Hakala, H. and M. Kohtamäki. 2011. Configurations of entrepreneurial- customer- and technology orientation: Differences in learning and performance of software companies. International Journal of Entrepreneurial Behavior \& Research 17(1): 64-81.

Harrigan, P., E. Ramsey and P. Ibbotson. 2009. Investigating the e-CRM activities of Irish SMEs. Journal of Small Business and Enterprise Development 16(3): 443-65.

Harrison, R. and C. Leitch. 1996. Discipline emergence in entrepreneurship: Accumulative fragmentalism or paradigmatic science. Entrepreneurship, Innovation and Change 5(2): 65-83.

Hennart, J. F. 2014. The accidental internationalists: a theory of born globals. Entrepreneurship Theory and Practice 38(1): 117-35.

Hermann, F. and H. Landstrom. 2015. What makes entrepreneurship research interesting? Reflections on strategies to overcome the rigour-relevance gap.

Hill, J. and L. T. Wright. 2000. Defining the scope of entrepreneurial marketing: a qualitative approach. Journal of Enterprising Culture 8(01): 23-46.

Hills, G. E., C. M. Hultman and M. P. Miles. 2008. The evolution and development of entrepreneurial marketing. Journal of Small Business Management 46(1): 99-112.

Hindmarsh, J. and N. Llewellyn. 2016. Video in Sociomaterial Investigations: A Solution to the Problem of Relevance for Organizational Research. Organizational Research Methods: 1094428116657595.

Hitt, M. A., R. D. Ireland, S. M. Camp and D. L. Sexton. 2001. Strategic entrepreneurship: Entrepreneurial strategies for wealth creation. Strategic management journal 22(6-7): 479-91.

Hmieleski, K. and R. Baron. 2008. Regulatory focus and new venture performance: a study of entrepreneurial opportunity exploitation under conditions of risk versus uncertainty. Strategic Entrepreneurship Journal 2(4): 285-99. 
Homburg, C. and O. Jensen. 2007. The Thought Worlds of Marketing and Sales: Which Differences Make a Difference? Journal of Marketing 71(3): 124-42.

Hutchinson, K., L. V. Donnell, A. Gilmore and A. Reid. 2015. Loyalty card adoption in SME retailers: the impact upon marketing management. European Journal of Marketing 49(3/4): 467-90.

Ireland, D. and J. W. Webb. 2007. A cross-disciplinary exploration of entrepreneurship research. Journal of management 33(6): 891-927.

Irvine, W. and A. R. Anderson. 2008. ICT (information communication technology), peripherality and smaller hospitality businesses in Scotland. International Journal of Entrepreneurial Behavior \& Research 14(4): 200-18.

Jarillo, J. C. 1989. Entrepreneurship and growth: The strategic use of external resources. Journal of Business Venturing 4(2): 133-47.

Johns, G. 2006. The essential impact of context on organizational behavior. Academy of management review 31(2): 386-408.

Johns, G. 2017. Reflections on the 2016 decade award: incorporating context in organizational research. Academy of Management Review 42(4): 577-95.

Johnson, J. E. 2004. Factors influencing the early internationalization of high technology startups: US and UK evidence. Journal of International Entrepreneurship 2(1-2): 139-54.

Jones, M. V., N. Coviello and Y. K. Tang. 2011. International Entrepreneurship research (1989-2009): A domain ontology and thematic analysis. Journal of Business Venturing 26(6): 632-59.

Jones, R. and J. Rowley. 2011a. Entrepreneurial marketing in small businesses: A conceptual exploration. International Small Business Journal 29(1): 25-36.

Jones, R. and J. Rowley. 2011b. Networks and Customer Relationships in a Small Software Technology Firm: A Case Study. Journal of Small Business and Entrepreneurship 24(1): 2948,152-3.

Karagozoglu, N. and M. Lindell. 2004. Electronic commerce strategy, operations, and performance in small and medium-sized enterprises. Journal of Small Business and Enterprise Development 11(3): 290-301.

Keating, A., S. Geiger and D. McLoughlin. 2014. Riding the practice waves: Social resourcing practices during new venture development. Entrepreneurship Theory and Practice 38(5): 120735 .

Ketchen Jr, D. J., J. C. Short and J. G. Combs. 2011. Is franchising entrepreneurship? Yes, no, and maybe so. Entrepreneurship Theory and Practice 35(3): 583-93. 
Khavul, S., L. Pérez-Nordtvedt and E. Wood. 2010a. Organizational entrainment and international new ventures from emerging markets. Journal of Business Venturing 25(1): 10419.

Khavul, S., M. Peterson, D. Mullens and A. A. Rasheed. 2010b. Going Global with Innovations from Emerging Economies: Investment in Customer Support Capabilities Pays Off. Journal of International Marketing 18(4): 22-42.

Kitching, J. and J. Rouse. 2016. Opportunity or dead end? Rethinking the study of entrepreneurial action without a concept of opportunity. International Small Business Journal 0(0): 0266242616652211.

Korczynski, M. 2005. The point of selling: Capitalism, consumption and contradictions. Organization 12(1): 69-88.

Kristiansen, S., J. Kimeme, A. Mbwambo and F. Wahid. 2005. Information flows and adaptation in Tanzanian cottage industries. Entrepreneurship \& Regional Development 17(5): 365-88.

Kuhn, K. M. and T. L. Galloway. 2015. With a Little Help From My Competitors: Peer Networking Among Artisan Entrepreneurs. Entrepreneurship: Theory \& Practice 39(3): 571600 .

Lechner, C., M. Dowling and I. Welpe. 2006. Firm networks and firm development: The role of the relational mix. Journal of Business Venturing 21(4): 514-40.

Leiblein, M. J. and J. J. Reuer. 2004. Building a foreign sales base: the roles of capabilities and alliances for entrepreneurial firms. Journal of Business Venturing 19(2): 285-307.

Lindman, M. 2013. How do SMEs bond to their retailers through value creation? Journal of Small Business and Entrepreneurship 26(5): 537-52.

Llewellyn, N. and R. Burrow. 2008. Streetwise sales and the social order of city streets. The British journal of sociology 59(3): 561-83.

Llewellyn, N. and L. Spence. 2009. Practice as a members' phenomenon. Organization Studies 30(12): 1419-39.

Löfgren, A. 2014. International network management for the purpose of host market expansion: The mediating effect of co-innovation in the networks of SMEs. Journal of International Entrepreneurship 12(2): 162-82.

Lowell, W. B., G. Page West, III, S. Dean, N. Teresa, N. C. Gaylen and Z. Andrew. 2003. Entrepreneurship Research in Emergence: Past Trends and Future Directions. Journal of Management 29(3): 285-308.

Macpherson, A. and R. Holt. 2007. Knowledge, learning and small firm growth: A systematic review of the evidence. Research Policy 36(2): 172-92. 
Madill, J. and L. C. Neilson. 2010. Web site utilization in SME business strategy: the case of Canadian wine SMEs. Journal of Small Business \& Entrepreneurship 23(4): 489-507.

Mahr, D., A. Lievens and V. Blazevic. 2014. The Value of Customer Cocreated Knowledge during the Innovation Process. Journal of Product Innovation Management 31(3): 599-615.

Marvel, M. R. and S. Droege. 2010. Prior tacit knowledge and first-year sales: learning from technology entrepreneurs. Journal of Small Business and Enterprise Development 17(1): 3244.

McDougall, P. P. and B. M. Oviatt. 2000. International Entrepreneurship: The Intersection of Two Research Paths. The Academy of Management Journal 43(5): 902-6.

McFarland, L. A. and R. E. Ployhart. 2015. Social media: A contextual framework to guide research and practice. Journal of Applied Psychology 100(6): 1653.

McKague, K. and S. Tinsley. 2012. Bangladesh's Rural Sales Program: Towards a scalable rural sales agent model for distributing socially beneficial goods to the poor. Social Enterprise Journal 8(1): 16-30.

McNaughton, R. B. 2002. The use of multiple export channels by small knowledge-intensive firms. International Marketing Review 19(2/3): 190.

Measson, N. and C. Campbell-Hunt. 2015. How SMEs use trade shows to enter global value chains. Journal of Small Business and Enterprise Development 22(1): 99-126.

Moen, Ø., Т. K. Madsen and A. Aspelund. 2008. The importance of the internet in international business-to-business markets. International Marketing Review 25(5): 487-503.

Moen, Ø. E., I; Gavlen, M. 2003. Use of the Internat in International Marketing: A Case Study of Small Computer Software Firms. Journal of International Marketing 11(4): 129-49.

Morgan-Thomas, A. and M. V. Jones. 2009. Post-entry Internationalization Dynamics Differences between SMEs in the Development Speed of their International Sales. International Small Business Journal 27(1): 71-97.

Moroz, P. and K. Hindle. 2011. Entrepreneurship as a process: Toward harmonizing multiple perspectives. Entrepreneurship Theory and Practice 36(4): 781-818.

Morris, M. H., R. Avila and E. Teeple. 1990. Sales Management As An Entrepreneurial Activity. Journal of Personal Selling \& Sales Management 10(2): 1-15.

Morris, M. H., M. Schindehutte and R. W. LaForge. 2002. Entrepreneurial marketing: a construct for integrating emerging entrepreneurship and marketing perspectives. Journal of marketing theory and practice 10(4): 1-19.

Morrissey, W. J. and L. Pittaway. 2006. Buyer-Supplier Relationships in Small Firms: The Use of Social Factors to Manage Relationships. International Small Business Journal 24(3): 27298. 
Mulford, M., J. Orbell, C. Shatto and J. Stockard. 1998. Physical attractiveness, opportunity, and success in everyday exchange. American journal of sociology 103(6): 1565-92.

Ngugi, I. K., R. E. Johnsen and P. Erdélyi. 2010. Relational capabilities for value co-creation and innovation in SMEs. Journal of Small Business and Enterprise Development 17(2): 26078.

Nguyen, T. H. and T. S. Waring. 2013. The adoption of customer relationship management (CRM) technology in SMEs: An empirical study. Journal of Small Business and Enterprise Development 20(4): 824-48.

O'Dwyer, M. and A. Ledwith. 2009. Determinants of new product performance in small firms. International Journal of Entrepreneurial Behavior \& Research 15(2): 124-36.

Perez, L., J. Whitelock and J. Florin. 2013. Learning about customers. European Journal of Marketing 47(3/4): 431-62.

Pinch, T. and C. Clark. 1986. The Hard Sell: 'Patter Merchanting' and the Strategic (Re)Production and Local Management of Economic Reasoning in the Sales Routines of Markt Pitchers. Sociology 20(2): 169-91.

Plattner, S. 1989. Economic Anthropology, Stanford University Press.

Plouffe, C. R., B. C. Williams and T. Wachner. 2008. Navigating difficult waters: Publishing trends and scholarship in sales research. Journal of Personal Selling \& Sales Management 28(1): 79-92.

Powers, T. L., W. S. Martin, H. Rushing and S. Daniels. 1987. Selling before 1900: A historical perspective. Journal of Personal Selling \& Sales Management 7(3): 1-7.

Prashantham, S. 2011. Social Capital and Indian Micromultinationals. British Journal of Management 22(1): 4-20.

Prashantham, S. and J. Birkinshaw. 2008. Dancing with Gorillas: How Small Companies Can Partner Effectively with MNCs. California Management Review 51(1): 6-23.

Prause, G., M. M. Mendez and S. Garcia-agreda. 2013. Attitudinal loyalty and trust in entrepreneurship: building new relationships. International Entrepreneurship and Management Journal 9(4): 531-40.

Preece, S. B., G. Miles and M. C. Baetz. 1999. Explaining the international intensity and global diversity of early-stage technology-based firms. Journal of Business Venturing 14(3): 259-81.

Priem, R. L. and J. E. Butler. 2001. Is the Resource-Based "View" a Useful Perspective for Strategic Management Research? The Academy of Management Review 26(1): 22-40.

Ramoglou, S. and E. W. Tsang. 2016. A realist perspective of entrepreneurship: Opportunities as propensities. Academy of Management Review 41(3): 410-34. 
Ranjan, K. R. and S. Read. 2016. Value co-creation: concept and measurement. Journal of the Academy of Marketing Science 44(3): 290-315.

Rauch, A. and S. A. Rijsdijk. 2013. The effects of general and specific human capital on longterm growth and failure of newly founded businesses. Entrepreneurship Theory and Practice 37(4): 923-41.

Raymond, L. and J. St-Pierre. 2004. Customer dependency in manufacturing SMEs: implications for R\&D and performance. Journal of Small Business and Enterprise Development 11(1): 23-33.

Rehme, J. and P. Svensson. 2011. Credibility-driven entrepreneurship A study of the first sale. The International Journal of Entrepreneurship and Innovation 12(1): 5-15.

Reid, S. W., A. H. Anglin, J. E. Baur, J. C. Short and M. R. Buckley. 2017. Blazing new trails or opportunity lost? Evaluating research at the intersection of leadership and entrepreneurship. The Leadership Quarterly.

Reuber, A. R. and E. Fischer. 2002. Foreign sales and small firm growth: the moderating role of the management team. Entrepreneurship Theory and Practice 27(1): 29-45.

Reuber, A. R. and E. Fischer. 2009. Signalling reputation in international online markets. Strategic Entrepreneurship Journal 3(4): 369-86.

Ries, E. 2011. The Lean Startup: How Constant Innovation Creates Radically Successful Businesses, Penguin Books Limited.

Roman, S., S. Ruiz and J. L. Munuera. 2002. The effects of sales training on sales force activity. European Journal of Marketing 36(11/12): 1344-66.

Ruiz-Arroyo, M., M. d. M. Fuentes-Fuentes, A. M. Bojica and L. Rodríguez-Ariza. 2012. Innovativeness and Performance in Women-Owned Small Firms: The Role of Knowledge Acquisition. Journal of Small Business and Entrepreneurship 25(3): 307-26,401.

Ruokonen, M., N. Nummela, K. Puumalainen and S. Saarenketo. 2008. Market orientation and internationalisation in small software firms. European Journal of Marketing 42(11/12): 1294315.

Sahlins, M. 1965. On the sociology of primitive exchange. The relevance of models for social anthropology 139: 236.

Saparito, P. A., C. C. Chen and H. J. Sapienza. 2004. The Role of Relational Trust in BankSmall Firm Relationships. Academy of Management Journal 47(3): 400-10.

Sarason, Y., T. Dean and J. F. Dillard. 2006. Entrepreneurship as the nexus of individual and opportunity: A structuration view. Journal of business venturing 21(3): 286-305.

Sarasvathy, S. D. 2001. Causation and effectuation: Toward a theoretical shift from economic inevitability to entrepreneurial contingency. Academy of management Review 26(2): 243-63. 
Sarasvathy, S. D. 2003. Entrepreneurship as a science of the artificial. Journal of Economic Psychology 24(2): 203-20.

Schatzki, T. R. 2005. Peripheral vision: The sites of organizations. Organization studies 26(3): 465-84.

Schumpeter, J. 1934. The Theory of Economic Development: An Inquiry into Profits, Capital, Credit, Interest and the Business Cycle. Cambridge MA, Harvard University Press.

Shane, S. 2012. Reflections on the 2010 AMR decade award: delivering on the promise of entrepreneurship as a field of research. Academy of Management Review 37(1): 10-20.

Shane, S. and S. Venkataraman. 2000. The Promise of Entrepreneurship as a Field of Research. Academy of Management Review 25(1): 217-26.

Shepherd, D. A. 2015. Party On! A call for entrepreneurship research that is more interactive, activity based, cognitively hot, compassionate, and prosocial. Journal of Business Venturing 30(4): 489-507.

Shepherd, D. A. and D. R. DeTienne. 2005. Prior Knowledge, Potential Financial Reward, and Opportunity Identification. Entrepreneurship: Theory \& Practice 29(1): 91-112.

Shepherd, D. A. and R. Suddaby. 2017. Theory Building: A Review and Integration. Journal of Management 43(1): 59-86.

Shiffman, S., A. A. Stone and M. R. Hufford. 2008. Ecological momentary assessment. Annu. Rev. Clin. Psychol. 4: 1-32.

Short, J. C., D. J. Ketchen, C. L. Shook and R. D. Ireland. 2009. The concept of "opportunity" in entrepreneurship research: Past accomplishments and future challenges. Journal of Management.

Sillince, J. A. 2007. Organizational context and the discursive construction of organizing. Management Communication Quarterly 20(4): 363-94.

Simpson, M. and A. J. Docherty. 2004. E-commerce adoption support and advice for UK SMEs. Journal of small business and enterprise development 11(3): 315-28.

Siu, W.-s. 2005. An institutional analysis of marketing practices of small and medium-sized enterprises (SMEs in China, Hong Kong and Taiwan. Entrepreneurship \& Regional Development 17(1): 65-88.

Smith, A. 1778. An Inquiry Into the Nature and Causes of the Wealth of Nations: By Adam Smith, LL. D. and FRS Formerly Professor of Moral Philosoophy in the University of Glasgow; in Two Volumes, W. Strahan, and T. Cadell, in the Strand.

Song, M., T. Wang and M. E. Parry. 2010. Do market information processes improve new venture performance? Journal of Business Venturing 25(6): 556-68. 
Spillecke, S. B. and M. Brettel. 2014. Antecedents and Performance Implications of a Sales Department's Learning and Entrepreneurial Orientation in SMEs. Journal of Small Business Management 52(3): 407-26.

Spiro, R. L., W. D. Perreault and F. D. Reynolds. 1976. The personal selling process: A critical review and model. Industrial Marketing Management 5(6): 351-63.

Stanworth, J., S. Brodie, T. Wotruba and D. Purdy. 2004. Outsourcing salesforces via selfemployment: the case of direct selling in the UK. Journal of Small Business and Enterprise Development 11(1): 50-9.

Stern, I. and J. D. Westphal. 2010. Stealthy footsteps to the Boardroom: Executives' backgrounds, sophisticated interpersonal influence behavior, and Board appointments. Administrative Science Quarterly 55(2): 278-319.

Tett, R. P. and D. D. Burnett. 2003. A personality trait-based interactionist model of job performance. Journal of Applied Psychology 88(3): 500.

Thorpe, R., R. Holt, A. MacPherson and L. Pittaway. 2005. Using knowledge within small and medium-sized firms: a systematic review of the evidence. International Journal of Management Reviews 7(4): 257-81.

Tolbert, P. S., R. J. David and W. D. Sine. 2011. Studying choice and change: The intersection of institutional theory and entrepreneurship research. Organization Science 22(5): 1332-44.

Tranfield, D., D. Denyer and P. Smart. 2003. Towards a methodology for developing evidenceinformed management knowledge by means of systematic review. British Journal of Management 14: 207-22.

Ulaga, W. and A. Eggert. 2006. Value-Based Differentiation in Business Relationships: Gaining and Sustaining Key Supplier Status. Journal of Marketing 70(1): 119-36.

Uy, M. A., M.-D. Foo and H. Aguinis. 2010. Using experience sampling methodology to advance entrepreneurship theory and research. Organizational Research Methods 13(1): 31-54.

Vaara, E. and R. Whittington. 2012. Strategy-as-practice: taking social practices seriously. The Academy of Management Annals 6(1): 285-336.

Verdin, J. A. 1986. Improving sales performance in a family owned business. American Journal of Small Business 10(4): 49-61.

Verhoef, P. C. 2003. Understanding the Effect of Customer Relationship Management Efforts on Customer Retention and Customer Share Development. Journal of Marketing 67(4): 30-45.

Viswanathan, M., S. Sridharan, R. Ritchie, S. Venugopal and K. Jung. 2012. Marketing interactions in subsistence marketplaces: A bottom-up approach to designing public policy. Journal of Public Policy \& Marketing 31(2): 159-77.

Vogel, P. 2016. From Venture Idea to Venture Opportunity. Entrepreneurship Theory and Practice. 
von Hippel, E. 2005. Democratizing innovation. Massachusetts, MIT Press.

Wallnöfer, M. and F. Hacklin. 2013. The business model in entrepreneurial marketing: A communication perspective on business angels' opportunity interpretation. Industrial Marketing Management 42(5): 755-64.

Webb, J. W., R. D. Ireland, M. A. Hitt, G. M. Kistruck and L. Tihanyi. 2011. Where is the opportunity without the customer? An integration of marketing activities, the entrepreneurship process, and institutional theory. Journal of the Academy of Marketing Science 39(4): 537-54.

Weitz, B. A. and K. D. Bradford. 1999. Personal selling and sales management: A relationship marketing perspective. Journal of the academy of marketing science 27(2): 241-54.

Welter, F. 2011. Contextualizing entrepreneurship — conceptual challenges and ways forward. Entrepreneurship Theory and Practice 35(1): 165-84.

Westhead, P., M. Wright and D. Ucbasaran. 2001. The internationalization of new and small firms: A resource-based view. Journal of business venturing 16(4): 333-58.

Whittington, R. 1996. Strategy as practice. Long Range Planning 29(5): 731-5.

Wiklund, J., P. Davidsson, D. B. Audretsch and C. Karlsson. 2011. The Future of Entrepreneurship Research. Entrepreneurship Theory and Practice 35(1): 1-9.

Wood, E., S. Khavul, L. Perez-Nordtvedt, S. Prakhya, R. Velarde Dabrowski and C. Zheng. 2011. Strategic commitment and timing of internationalization from emerging markets: evidence from China, India, Mexico, and South Africa. Journal of Small Business Management 49(2): 252-82.

Wood, M. S. and W. McKinley. 2010. The production of entrepreneurial opportunity: a constructivist perspective. Strategic Entrepreneurship Journal 4(1): 66-84.

Yang, W.-T. and C.-M. Kuo. 1996. A Practical Approach to Sales Force Compensation Plan in a Small Business. Journal of Entrepreneurship 5(2): 209-22.

Yli-Renko, H., E. Autio and H. Sapienza. 2001a. Social capital, knowledge acquisition, and knowledge exploitation in young technology-based firms. Strategic Management Journal 22: 587-613.

Yli-Renko, H. and R. Janakiraman. 2008. How Customer Portfolio Affects New Product Development in Technology-Based Entrepreneurial Firms. Journal of Marketing 72(5): 13148.

Yli-Renko, H., H. J. Sapienza and M. Hay. 2001b. The role of contractual governance flexibility in realizing the outcomes of key customer relationships. Journal of Business Venturing 16(6): 529-55.

Yu, J., B. Gilbert and B. Oviatt. 2011. Effects of alliances, time, and network cohesion on the initiation of foreign sales by new ventures. Strategic Management Journal 32(4): 424-46. 
Zahra, S. 2007. Contextualizing theory building in entrepreneurship research. Journal of Business Venturing 22(3): 443-52.

Zahra, S. A., B. P. Matherne and J. M. Carleton. 2003. Technological resource leveraging and the internationalisation of new ventures. Journal of International Entrepreneurship 1(2): 16386.

Zahra, S. A., H. J. Sapienza and P. Davidsson. 2006. Entrepreneurship and dynamic capabilities: a review, model and research agenda. Journal of Management studies 43(4): 91755.

Zahra, S. A. and M. Wright. 2011. Entrepreneurship's next act. The Academy of Management Perspectives 25(4): 67-83.

Zahra, S. A., M. Wright and S. G. Abdelgawad. 2014. Contextualization and the advancement of entrepreneurship research. International small business journal 32(5): 479-500.

Zhao, L. and J. D. Aram. 1995. Networking and growth of young technology-intensive ventures in China. Journal of Business Venturing 10(5): 349-70.

Zundel, M., R. MacIntosh and D. Mackay. 2016. The utility of video diaries for organizational research. Organizational Research Methods: 1-26. 